\title{
Impact of Transgenic Technologies on Functional Genomics
}

\author{
Cooduvalli S. Shashikant ${ }^{1 \star}$ and Frank H. Ruddle ${ }^{2}$ \\ ${ }^{1}$ Dept. Dairy and Animal Science, College of Agricultural \\ Sciences, 324 Henning, University Park, PA 16802, USA \\ ${ }^{2}$ Depts of MCDB and Genetics, Yale University, New \\ Haven, CT 06511, USA
}

\begin{abstract}
Gene transfer technologies in mammals are the focus of renewed interest owing to the recent emphasis on analyzing gene function in the postgenomic era. Three important developments in this area include transgenics, gene targeting and nuclear transfer or animal cloning. These technological innovations have enhanced our ability to analyze gene function at the level of the whole organism and have provided the means to modify gene expression. This review discusses the origins and current status of transgenic technologies. Various applications and technologies including chromosome engineering, stem cells, gene traps and modification of livestock are presented. The impact of mouse technologies and genomics on functional analyses is also discussed.
\end{abstract}

\section{Introduction}

Gene transfer technologies in mammals are the focus of renewed interest owing to the recent emphasis on analyzing gene function in the post-genomic era (Galas and McCormack, 2002). As large numbers of genes are identified, linking the sequence of a gene to its biological function has assumed an industrial-scale importance. At present, large scale, rapid methods are used to identify sequence motifs, potential functional domains and possible function. Remarkable insights are further gained by largescale expression analysis and protein-interaction mapping studies that successfully profile when genes are active during development, the cell cycle and differentiation. These studies are providing information on placing gene products in a particular pathway such as signal transduction transcriptional cascades, transport or metabolic pathways. This advance raises the issue of determining gene function at the level of the whole organism, preferably in a model system with relevance to human biology. The purpose of this inquiry is two fold: one intellectual, aimed at phenotypic assessment of gene function in the life of an organism; and the second technological, aimed at the exploitation of genes and their products for therapeutic or commercial purposes. This review provides a framework for examining how gene transfer technologies contribute to our understanding of genome interactions and advance our

*For correspondence. Email css13@psu.edu. biotechnological capabilities.

Twentieth century genetics was dominated by the idea of introducing exogenous genetic material into the genome of experimental organisms. The foundation of bacterial genetics lies in the discovery of transformation, conjugation and transduction. A combination of bacterial gene transfer technologies and molecular biology tools resulted in the birth of recombinant DNA technology in the seventies. The progress made in bacterial genetics inspired development of similar methods to study mammalian genetics. Here, mammalian gene transfer technology is broadly considered under three technological breakthroughs achieved during the past two decades: (a) transgenic technology; (b) gene targeting; and (c) nuclear transfer or 'cloning'. In this review, we describe the emergence of these technologies and current advances in the analysis of mammalian gene function.

\section{Historical Perspective}

\section{Transgenic Technologies}

Several reviews have examined how transgenic methods were developed simultaneously in several laboratories (Scangos and Ruddle, 1981; Gordon, 1993; Hogan et al., 1994; Palmiter, 1998; Galas and McCormack, 2002). Advances in different areas including cell culture, somatic cell genetics, animal virology and mouse embryology culminated in the development of methods for generation of transgenic animals. In the author's (FHR) laboratory, the discovery of the transgenic method was the culmination of a long-standing interest in mammalian gene transfer beginning with early studies in somatic cell genetics. Although somatic cell genetics is better known for its success in gene mapping, it also provided early methods of gene transfers into mammalian cells (Ruddle, 1981). When cells from two different species were fused, the resulting hybrid cells partially lost chromosomes belonging to one of the donor species. Thus, it was possible to establish hybrid cells that retained a defined set of donor chromosomes in the recipient cells. Subsequently, microcells or cell free extracts were used to transfer single or a few chromosomes into recipient cells. Chromosomal fragments of varying sizes were transferred by these techniques and identified by assaying for the transfer of selective markers.

The first demonstration of DNA mediated gene transfer in mammalian cells was reported almost 40 years ago (Szybalska and Szybalski, 1962). This involved development of drug resistant mutant cell lines deficient in hypoxanthine phosphoribosyl transferase (HPRT) activity and the design of a now widely used selection system, named HAT (for Hypothanthine, Aminopterin and Thymidine). Mutant cells (HPRT negative) were transformed with DNA and rare HPRT positive transformants were selected by culturing the DNA treated 
cells in HAT selection medium. DNA-mediated gene transfers were not consistently reproducible until the role of calcium phosphate in forming DNA precipitates capable of uptake by cells was fully appreciated (Graham and Van der Eb, 1973). Subsequently, efficiency of gene transfer in rescuing deficient cells in selection media was variously demonstrated (Scangos and Ruddle, 1981).

The efficiency of gene transfer by the calcium phosphate precipitation method was low, at a rate of one in $10^{5}$ cells. In an attempt to increase the efficiency of transfer, exogenous DNA was directly injected into tissue culture cells with the aid of micropipets directed by micromanipulators (Graessmann et al., 1979; Capecchi, 1980). Transformation frequencies obtained by microinjection were as high as $20 \%$ (Capecchi, 1980). Such a high efficiency of transformation provided an impetus to consider direct introduction of DNA into the germ line of an experimental organism. Soon, Gordon et al successfully demonstrated genetic transformation and stable inheritance of an exogenous gene injected into the pronucleus of mouse zygotes (Gordon et al., 1980). This feat was rapidly reproduced in several laboratories and for the first time there was a tremendous opportunity for modifying the whole organism by what was termed a "transgenic" procedure (Gordon and Ruddle, 1981). The term 'transgenic' is now extensively used to describe a variety of gene transfer methods in several organisms.

The development of transgenic technology owes much to the convergence of gene transfer technologies with the efforts of many researchers studying early mouse development by culturing of eggs, generating chimeras and manipulating blastula/morula staged embryos (Hogan et al., 1994, Brinster, 1998; Hammer, 1998; Gardner, 1998). Success of the pronuclear DNA injection method of generating transgenic mice was preceded by two competing ideas for transforming the mouse germ line, one based on retroviral infections and the other based on embryonal carcinoma (EC) cells. The feasibility of using retroviral vectors in generating transgenic mice stems from the observation that retroviruses that infect intact, dividing mouse embryos are transmitted as a Mendelian trait to offspring (Jaenisch, 1976). Based on these observations, retroviral vectors were developed to generate transgenic mice (Jahner et al., 1985; van der Putten et al., 1985). Unlike other methods, retroviral vectors have the advantage of precisely integrating a single copy of the vector directly into the genome without the expression of the viral genome in the recipient cells. The inability to obtain consistent, longterm expression of the transgene has undermined the usefulness of retroviral vectors in generating transgenic mice. However, retroviral vectors continue to find applications in gene therapy and gene transfers in avian embryos (Friedmann, 1992; Federspiel and Hughes, 1997; Solaiman et al., 2000).

The idea of gene transfer through EC cells comes from the observation that when injected into mouse blastocysts, these cells contributed to somatic tissues and germ lines of resultant chimeras (Brinster, 1974, Mintz and Illmensee, 1975; Papaioannou et al., 1975). Transfected EC cells were then demonstrated to transmit transgenes through germ lines, but they were limited by their capacity to contribute to germ lines. The lack of reproducibility of original observations by others also diminished the usefulness of this approach. The experiments described below were forerunners of manipulating mouse embryos via embryonic stem (ES) cells, a predominant method now used to generate knockout mice.

Although pronuclear DNA injection remains a common method of generating transgenic animals, the laborintensive nature of the technique has prompted many to look for other alternatives. Using sperm as carriers for the introduction of exogenous DNA at the time of fertilization is an ingenious idea (Gandolfi, 2000). Sperm are known to bind to exogenous DNA by a poorly understood mechanism. Initial reports of success at generating transgenic mice by this technique led to widespread interest because of its simplicity and applicability to many species (Lavitrano et al., 1989). However, a number of laboratories failed to reproduce these results, thereby diminishing their application (Brinster et al., 1989). In recent years, sperms introduced by intracytoplasmic injections instead of in vitro fertilization have successfully generated transgenic progenies at a rate comparable to that of pronuclear injections (Perry et al., 1999). Although its application has remained relatively uncommon in mice, sperm mediated transgenesis is now an established technique in Xenopus, where no other methods exist for generating transgenic frogs. (Kroll and Amaya, 1996; Amaya and Kroll, 1999; Beck and Slack, 2001).

\section{Gene Targeting}

Gene targeting techniques emerged from the desire to study gene mutations in the whole organism and involved developing methods to mutate the mouse genome in cultured cells and transmit the mutation through the mouse germ line (Capecchi, 2001; Evans, 2001; Smithies, 2001; Muller, 1999). Gene targeting was favored over methods to create random mutagenesis, then considered impractical in mice. The possibility of introducing specific mutations was underscored by initial observations coming from gene transfer experiments using drug resistant cell lines described above. The existence of active recombination machinery in somatic cells was inferred by studying the mode of integration of drug resistance genes (Folger et al., 1982; 1985). Genes introduced in cells often recombined and integrated as tandem repeats in the genome at random sites. In an effort to improve the efficiency of gene transfers, flanking sequences were included, which in turn suggested the possibility of recombination at the endogenous locus by homology with the flanking sequences (Luciw et al., 1983; Kucherlapati et al., 1984; Smithies et al., 1985).

The potential of transmitting a modified gene through mouse germ line was realized via development of the ES cell technology (Evans, 2001). Interest in culturing cells of embryonic origin came from the observation that the 129/ Sv strain of mice contained testicular teratomas, a mixture of cell types including teratocarcinomas, some of which could be serially transplanted and maintained (Stevens, 1967). Cell lines established from these teratocarcinomas showed a propensity to differentiate into different cell types, typical of early embryonic differentiation (Evans, 1972). 
Although the application of EC cells for gene transfer was limited, these initial experiments led to the isolation of ES cells from mouse blastocysts (Evans and Kaufman, 1981). When injected into mouse blastocysts, ES cells were shown to contribute extensively to different tissues including the germ line (Bradley et al., 1984; Evans et al., 1985). Methods to target genes into ES cells were soon developed in several laboratories. A positive-negative selection scheme that allows isolation of cells containing the correct targeting event was developed (Mansour et al., 1988). In this scheme, the integration of the DNA targeting cassette at the endogenous locus by homologous recombination was selected for using the neomycin (neo $R$ ) gene /G418 selection system. In contrast, integrations at random sites were negatively selected for using the tk gene. This positive-negative selection scheme is popular in designing "knockout" gene-targeting strategies. Besides HPRT, early examples of knockout mouse include generation of null mutations for $c$-abl and $\beta_{2}$-microglobulin genes (Doetschman et al., 1987; 1988; Kuehn et al., 1987; Koller et al., 1989; Schwartzberg et al., 1989; Zijlstra et al., 1989). Currently more than 7,000 genes have been analyzed for function by knockout strategies in the mouse. Information on the available knockout mice can be searched at the Jackson Laboratory Transgenic/Targeted Mutation Database (http://tbase.jax.org).

\section{Cloning}

Cloning has been widely practiced in plants and lower animals. However, cloning of mammals has become feasible only after overcoming major technical barriers and crossing certain intellectual boundaries (McLaren, 2000; Solter, 2000). The origins of mammalian cloning can be traced back to attempts to develop nuclear transfer techniques or fusion of somatic cells with unfertilized or fertilized eggs using Sendai virus, a fusion agent commonly used in generating somatic cell hybrids (Bromhall, 1975). These experiments were further galvanized by an effort to induce parthenogenetic development and to examine the concept of progressive loss of potential of non-zygotic cells in supporting embryonic development. Although Illmensee and Hoppe (1981) claimed live birth of mice from nuclear transfer of nuclei derived from inner cell mass cells of a blastocyst stage embryo into an enucleated zygote, these results were not reproducible. Nuclear transfer experiments carried out independently in Solter and Surani's laboratories failed to clone mice, but led to the discovery of the imprinting mechanism (McGrath and Solter, 1984; Barton et al., 1984). This discovery demonstrated that non-equivalent contributions from the male and the female pronuclear genomes were essential for embryonic development. The genomes of the male and female gametes undergo differential epigenetic modification, making each other's contribution an essential feature of normal development. A number of imprinted genes have been discovered (Solter, 1998; Ferguson-Smith and Surani, 2001). These studies, although fascinating, designated cloning mice as conceptually difficult task.

However, attempts at cloning continued among other mammals (Willadsen, 1986). Experiments carried out using enucleated unfertilized oocytes (instead of enucleated fertilized eggs), as recipients were successful. In early experiments, donor nuclei were isolated from cleavage stage embryos (Willadsen, 1986; Prather et al., 1987; Collas et al., 1992; Collas and Barnes, 1994; Campbell et al., 1993). The embryonic nature of the donor nuclei was thought to be essential for successful cloning. Followed by success in cloning sheep from nuclei isolated from cultured cell lines, Wilmut and Campbell reported the first mammalian cloning from an adult donor nucleus (Campbell et al., 1996; Wilmut et al., 1997). These experiments carried out in sheep have now been reproduced in other mammals including mice (Cibelli et al., 1998; Wakayama et al., 1998; Baguisi et al., 1999; Onishi et al., 2000; Polejaeva et al., 2000).

The success of mammalian cloning is due to a switch from a fertilized zygote to unfertilized oocytes as recipients (Solter, 2000). Second, the realization that the relative cell cycle status of the donor nuclei and recipient cytoplasm is important led to improved experimental strategies for egg activation and synchronization. Although cloning efficiency remains poor, the importance of the technique for commercial exploitation of agricultural animals and the biomedical value of therapeutic cloning has become increasingly evident. The nuclear transfer technique has provided a novel route to transgenics and gene targeting in mammals (Schneike et al., 1999; McCreath et al., 2000; Denning et al., 2001; Lai et al., 2002). Nuclei isolated from cells in culture manipulated for transgene expression or gene inactivation are introduced into enucleated eggs. Cloned animals invariably transmit the introduced gene modification. Cells in culture can be screened for appropriate levels of transgene expression prior to nuclear transfer. In animals where the efficiency of transgenic method is poor, cloning provides a powerful alternative.

\section{Current Status}

Although the basic methods for generating transgenic and gene targeting in mice have remained remarkably unchanged, a number of strategies have been developed that significantly enhance the efficiency of gene transfer. The first category focuses on conditional alterations in gene expression (Sauer, 1998; Gingrich and Roder, 1998; Nagy, 2000; Mills, 2001; Lewandoski, 2001). The second category focuses on analyzing large genomic regions by devising methods to manipulate large-inserts in mice (Shashikant et al., 1998a; Copeland et al., 2001; Heintz, 2001; Muyers et al., 2001; Mills and Bradley, 2001; Yu and Bradley, 2001).

\section{Condtional Alterations in Gene Expression}

Many genes play multiple roles during the life of an organism through embryonic development, differentiation and aging. Either transgenic expression or gene targeting can study the earliest, critical function of the gene. However, the resulting phenotype of such manipulations is often complex and lethal, thereby excluding the study of later functions of the same gene. To overcome these problems, it is necessary to alter gene expression conditionally, in a selective, timely and controlled manner. This can be achieved by devising an inducible gene expression system in which the activity of the target gene is placed under the 
control of cis-acting elements, which respond to specific inducer or effector molecules. In the absence of the inducer/ effector, the state of target gene expression remains unaltered. Change in the level of the target gene expression is achieved by the introduction of the inducer/effector molecule into the system (Lewandoski, 2001).

The induction can be achieved in a single transgenic line, especially when the inducer is a small molecular compound that can be administered to mice by injection or feeding. In contrast, binary transgenic systems were designed when the inducer/effector required for gene expression is a transcription factor or a recombinase (Byrne and Ruddle, 1989; Ornitz et al., 1991; Lakso et al., 1992; Gu et al., 1994). The binary system consists of two transgenic mouse lines, the first of which contains a target transgene whose activity remains unaltered unless crossed with a second transgenic mouse line. The second mouse line contains an 'effector' transgene regulated by a tissuespecific or inducible promoter. The expression of the 'effector' in the second line should not affect the normal mouse development presumably for lack of its target promoter in the second mouse genome. When these two transgenic lines are crossed, the expression of the target gene is altered in those progenies that inherit both transgenes. In some instances, the principles of binary and inducible systems are combined to elicit conditional alterations in gene expression (Lewandoski, 2001).

A variety of inducible gene expression systems are currently in use for transgenic mice (Gingrich and Roder, 1998; Mills, 2001). Inducers such as heavy metal ions (zinc or cadmium), heat shock, antibiotics, steroid hormones or IPTG are used to induce gene expression in transgenic mice. There are several problems associated with inducible and binary transgenic systems. First, the response elements generally lack specificity, as they respond to other activators beside their main inducers, resulting in leaky or uncontrolled basal expression. Second, the inducer/effector may affect expression of endogenous genes other than the transgene, making it difficult to absolutely correlate the resulting phenotype to the induction of transgene expression. Very often, the systemic concentration of the required inducer may have deleterious effects on mice unrelated to target gene expression. Thus, the challenge is to design an inducer that at low concentrations results in dose-dependent induction of high levels of target gene expression by interacting with specific response elements, which in turn are refractory to other inducing factors affecting mouse developmental and differentiation processes.

An early example of inducible transgenic mice is the metal-induced growth hormone mouse (Palmiter et al., 1982). In this experiment, the rat growth hormone gene was placed under the control of a mouse metallothionein promoter. Transgenic mice fed with zinc showed dramatic growth, and the experiment inspired many with the power of transgenic technology. However, the metallothionein promoter also responds to other trans-acting factors, some of which are constitutively expressed, resulting in a basal level of expression, thus limiting its use. The interferoninducible promoters show rapid and high level induction of transgene expression (Arnheiter et al., 1990). However, in addition to leakiness of the promoter, interferons evoke diverse physiological responses in mice.

Bacterial Inducible Systems

Two bacterial inducible systems employed in transgenic studies are based upon the lac and tet operons (Gingrich and Roeder, 1998; Mills, 2001). The lac repressor (lacR) binds to the lac operator sequences and inactivates transcriptional activity of the promoter. The synthetic inducer IPTG relieves this repression, activating transcription by several hundred fold. Thus, an inducible transgenic system can be constructed in which the lac operator sequences are placed in the promoter of the target gene. The activity of the target promoter is repressed in the presence of lac repressor encoded by lacl gene. The activity of lacl can be regulated by a ubiquitous or a tissue specific promoter. In the absence of IPTG, the target gene expression is repressed. Feeding transgenic mice with IPTG relieves the repression and activates the target gene. Although the lac operator system is tightly regulated in the bacterial system, several problems associated with the mammalian expression have made this system less attractive. More recently, the lacoperator/repressor system has been thoroughly modified to achieve efficient regulation in mice (Cronin et al., 2001). Some of these modifications involved changes in the lacl gene for better codon usage, elimination of cryptic splicing sites, translational block and removal of sequences prone to silencing by methylation. An improved lac-operator/repressor based transgenic system may provide several advantages of achieving highly specific and reversible induction of target genes (Cronin et al., 2001).

A second inducible gene expression system is based upon the tetracycline operator/repressor (Gossen and Bujard, 1992; Gossen et al., 1995). In this system, the tetracycline repressor (TetR) binds to tetracycline (or doxycycline) and tetracycline operator (tetO) sequences. The DNA binding domain of tet $R$ is fused to a transcriptional activator domain of a viral proteinVP16, to create a chimeric activator molecule, tTA. Currently, two versions of the tet inducible systems are in use: tTA (tet-off) and reverse, rtTA (tet-on; Gossen and Bujard, 1992; Gossen et al., 1995). In the tTA system, the absence of an inducer results in binding of tTA to the operator sequences resulting in the transcriptional activation of the target gene. In the presence of an inducer, the binding of tTA to operator sequences is prevented thereby inhibiting target gene expression. In the reverse system, rtTA requires an inducer for its binding to the operator sequence. Thus, in the absence of an inducer, rtTA does not bind to the operator, resulting in transcriptional inactivation of the target gene. In the presence of an inducer, target gene expression is achieved. The two systems differ from one another in their kinetics of induction of gene expression. In the tTA system, the target gene expression is prevented by continuous administration of the inducer. Removal of the inducer results in induction of gene expression, which is gradual, depending upon the clearance of the inducer from the system. In the rtTA system, induction of gene expression is achieved rapidly by administration of the inducer, but suppression of gene expression will be slow, dependent upon clearance of the 
inducer from the system. A number of modifications to improve the tet systems are currently being tested. These improvements are aimed at altering codon usage, promoter context of tet operator sequences, transactivation domain and sensitivity to the inducer. Despite concerns about toxicity of long term use of antibiotics and induction kinetics, the tet system has found several applications in mouse transgenic studies (Lewandoski, 2001).

\section{Steroid Hormone-based Inducible Systems}

Steriod response elements are among the bestcharacterized cis-acting regulatory sequences. Accordingly, inducible transgenic systems based on glucocorticoid, estrogen, progesterone and other ligands capable of interactions with steroid response elements have been used in transgenic mice studies (Gingrich and Roder, 1998; Mills, 2001). A disadvantage of the system is that several endogenous genes carrying steroid response elements may respond to the inducer and endogenous hormone levels could induce transgene expression, resulting in leaky expression or inappropriate transgene expression. One attractive steroid based inducible system uses a ligand binding domain of the progesterone receptor that has been mutated to prevent binding to progesterone (Wang et al., 1994). Instead, the mutated progesterone receptor binds to antiprogestins such as RU486. A further modification of this system is fusion of the mutated ligand-binding domain with the VP16 activation domain and a yeast GAL4 DNA binding domain, creating a chimeric effector molecule, termed GLVP. In the absence of RU486, GLVP remains inactive bound by an ubiquitous heat shock protein, HSP90. In the presence of RU486, GLVP is released from HSP90. GLVP then forms a functional homodimer that is translocated into the nucleus, where the Gal4 DNA binding domain recognizes yeast UAS sequences activating transcription of UAS linked target genes (Wang et al., 1994; Wang et al., 1997; Wang et al., 1999).

Several laboratories have been developing Drosophila molting hormone, ecdysone-based inducible systems (No et al., 1996; Albanese et al., 2000; Hoppe et al., 2000). A chimeric molecule comprising the ecdysone receptor linked to the VP16 activator is used to induce gene expression of a target gene linked to ecdysone response elements. In response to ecdysone, the chimeric molecule forms a dimer with the retinoid $X$ receptor and activates target gene expression. To circumvent activation of endogenous genes that are responsive to retinoid receptors, a hybrid receptor containing Drosophila and Bombyx ecdysone receptor molecules has been generated (Hoppe et al., 2000). The hybrid receptor does not require retinoid receptor for its activity. Several potential inducers from plant sources have been tested for their ability to induce ecdysone receptor activity with the hope that these compounds do not activate endogenous gene expression in mammalian cells (Saez et al., 2000).

Site-specific DNA Recombinase Based Transgenic Systems

Binary systems based on site-specific recombination offer attractive methods for achieving conditional alteration of gene expression in transgenic mice. Cre recombinase from bacteriophage $\mathrm{P} 1$ catalyzes deletion or inversion of intervening sequences flanked by direct or inverted repeats of a $34 \mathrm{bp}$ recognition sequence, loxP (Sauer and Henderson, 1988). A transgenic line is established in which Cre recombinase activity is placed under the control of a temporal specific or tissue-specific promoter. A second transgenic line is established in which the DNA sequences to be removed are flanked by two loxP ("floxed") sites. The two mouse lines are crossed and in the progeny inheriting Cre recombinase and the floxed gene, temporal or tissue specific deletion occurs. To achieve tissue-specific activation of gene expression, the floxed sequences are inserted to disrupt the promoter activity of the gene. Recombinase mediated removal of these sequences brings the necessary sequences in contiguity for transcription and translation to occur. In contrast, for inactivation, loxP is placed in regions flanking coding regions of the gene. Removal of loxP and the intervening coding region by Cre recombinase results in gene inactivation.

Cre transgenic mouse lines generated by combining various inducible and tissue-specific promoters become valuable resources, since these lines can be utilized by several investigators to alter the expression of different genes. Many interesting Cre recombinase mice are available, for instance Cre recombinases expressed only in spermatocytes during the meiotic phase of cell division, in one-cell embryos or in a few defined brain cells. A periodically updated list of Cre recombinase lines for conditional gene expression is available (http:// www.mshri.on.ca/nagy/Cre-pub.html). The advantage of the binary system is that multiple crosses of the conditional Cre line with selected murine lines containing "floxed" genes can be carried out to achieve different types of tissuespecific alterations in gene expression. For example, the same neuron specific Cre deleter line might be crossed with "floxed" genes creating single "knockout"lines of serotonin receptor subtypes. The single "knockout" lines might then be bred to produce double "knockouts" of the serotonin receptors. Depending on the experimental design, this methodology provides a powerful analytic tool and creates an extensive database on gene function (Sauer, 1998; Nagy, 2000; Gertsenstein et al., 2002).

A second site-specific recombinase system used for altering gene expression in mice is based upon Flp recombinase from Saccharomyces cerevisiae, (O'Gorman et al., 1991). Similar to Cre recombinase DNA recombination is catalyzed between two 34 bp FRT recognition sites. Although initial applications of Flp/FRT transgenics were hindered by technical difficulties, recent modifications made to the system, including engineering a Flp variant that functions at $37^{\circ} \mathrm{C}$, and improving conditions for more efficient recombination will find more applications in mice (Buchholz et al., 1998; Dymecki et al., 1998; Schaft et al., 2001; Awatramani et al., 2001).

\section{Manipulating Large Genomic Regions}

Transgenic mice produced by conventional manipulation of small DNA constructs by routine subcloning procedures often proved to be inadequate as they failed to contain all the necessary regulatory elements for achieving proper transgene regulation in mice. Furthermore, many genes 
and gene clusters are several kb long with regulatory elements scattered at considerable distances from the coding region, thereby making it necessary to analyze large DNA fragments in mice. Three lines of technological developments have addressed these concerns. First, cloning vehicles that hold large-inserts allow examination of large segments of genome by transgenic analysis (Peterson et al., 1998; Shashikant et al., 1998a; Giraldo and Montoliu, 2001; Heintz, 2001). Second, methods to manipulate large-inserts by recombinogenic targeting methods allow functional analysis of large inserts (Shashikant et al., 1998a; Copeland et al., 2001, Muyrers, 2001). Third, using the Cre/loxP system, it is possible to engineer chromosomal deletions, inversions or translocations directly in mice (Yu and Bradley, 2001).

\section{Large-insert Transgenics}

Large-insert cloning vehicles that hold several hundred kbs of DNA fragments were first developed by adapting the yeast origin of replication and telomeres along with yeast selectable markers. Yeast artificial chromosomes (YACs) can hold up to $2000 \mathrm{~kb}$. Bacterial artificial chromosomes (BACs) containing the F-factor ori and P1 artificial chromosomes (PACs) containing P1 bacteriophage replicon that can hold inserts in the range of $300 \mathrm{~kb}$ were developed later as additional large-insert vehicles (Burke et al., 1987; Sternberg et al., 1992; Shizuya et al., 1992; lannou et al., 1994). Although YACs provide a larger cloning capacity and easier insert manipulation, there are significant drawbacks in the use of YACs for transgenic studies. These include poor cloning efficiency and chronic chimerism in most YAC libraries. In contrast, bacterial based vectors, BACs and PACs, are relatively easy to handle and the inserts are more stable and less prone to chimerism. The yeast-bacteria shuttle vector, pClasper, combines the advantages of BACs and YACs, without their apparent disadvantages (Bradshaw et al., 1995). The DNA inserts cloned in pClasper are stable in yeast and are manipulated using the yeast genetic system. Subsequently, the DNA inserts are shuttled into bacteria and then isolated for generating transgenic mice (Bradshaw et al., 1996). YACs can be introduced into mice either by direct pronuclear injection or by ES-cell technology (Lamb and Gearhart, 1995; Peterson et al., 1997). In the latter method, yeast spheroplasts containing YACs are fused with ES cells. Alternatively, YACs are introduced into ES cells by lipofection. ES cells carrying YAC DNA are then injected into mouse blastocysts to create chimeric mice. The inserts from BACs and pClasper are introduced into mice by direct pronuclear injections. Large-insert cloning vectors make it possible to examine large genes and gene complexes; to identify long-acting cis-regulatory elements; to create transgenic models that more faithfully reproduce the functional aspects of endogenous loci; to complement known genetic mutations; and finally, to study higher order chromosomal structures such as X-chromosome inactivation.

\section{Recombinogenic Targeting}

Molecular sub-cloning techniques based on availability of unique or rare restriction sites are inadequate in cloning and modification of DNA inserts for production of large insert transgenics. In the post genomic era, refinement of functional analysis of genes will require modifications of large inserts. Precise alterations in both the coding and regulatory sequences are essential for understanding the role of specific sequences in gene function. Methods based on homologous recombination can be used to generate DNA constructs for transgenic analysis. In yeast, compared to other organisms, the frequency of homologous recombination is relatively high (Szostak et al., 1983). Transformed DNA (lacking autonomous replicating sequences) invariably integrates into the yeast genome by homologous recombination. Homologous recombination in yeast has been extensively used to create yeast gene knockouts (Kumar and Snyder, 2001). When transformed with linear vectors (containing ARS sequences) that have regions of homology to yeast genes, circularization of the vector is observed by incorporating missing regions of the gene from yeast genome by a 'gap repair' mechanism. This principle has been extended to capture and modify large inserts in pClasper by simple transformation and selection protocols in yeast (Bradshaw et al., 1995; 1996; Chiu et al., 2000).

Unlike yeast, bacterial recombination machinery has been less thoroughly exploited to modify gene inserts for functional analysis. Linear DNA transformed into bacteria is unstable because of its susceptibility to the action of Rec BCD exonucleases (Kowalczykowski et al., 1994; Myers and Stahl, 1994). Two approaches are used to enhance stability of linear DNA for recombinogenic targeting. In the first approach, RecBCD exonuclease deficient strains have been developed into which linear DNA molecules can be targeted (Bubeck et al., 1993; Oliner et al., 1993). In the second approach, linear DNA fragments are flanked by Chi sites (5' GCTGGTGG 3'), which attenuate RecBCD exonuclease activity and at the same time facilitate RecBCD mediated recombination (Dabert and Smith, 1997; Anderson and Kowalczykowski, 1997; Jessen et al., 1998). Another approach to targeted modifications of large inserts is to provide a recombination function in bacteria either through a plasmid containing recA or activating phage encoded recE and recT genes (ET system; Yang et al., 1997; Zhang et al., 1998; Lee et al., 2001). A number of applications of recombinogenic targeted modifications for functional analysis, ranging from generating of targeting constructs to reporter gene analysis are now emerging (Copeland et al., 2001; Heintz, 2001).

\section{Chromosome Engineering}

Chromosome engineering refers to generation of Cre/lox $P$ mediated chromosomal rearrangements in mice (Mills and Bradley, 2001; Yu and Bradley, 2001). Although initial application of Cre technology was directed towards deleting small portions of genes, it was soon realized that Cre catalyzes recombination over large genome segments flanked by loxP sites (Ramirez-Solis et al., 1995). A number of chromosomal rearrangements including deletions, duplications, inversions and translocations can be induced by strategically engineering the position and orientation of Iox $P$ sites in the mouse genome utilizing homologous recombination strategies in ES cells (Yu and Bradley, 2001). 
Cre mediated recombination events leading to chromosomal rearrangements can be identified in mice generated through ES cell chimeras by visible markers (for example coat color markers) tagged to loxP sites. A typical targeting strategy involves introduction of two loxP sites, each flanked by portions of the HPRT gene (Ramirez-Solis et al., 1995; Liu et al., 1998). Cre mediated recombination (in this examples, deleting the DNA between the lox P sites) reconstitutes the HPRT gene. This event is selected by growing ES cells in HAT medium. Furthermore, the $5^{\prime}$ loxP site is flanked by a tyrosinase gene and the $3^{\prime}$ loxP site is flanked by agouti gene, which encode different coat colors when inherited independently. Inheritance of both genes in the same mouse identifies a chromosomal rearrangement and results in a mouse with a distinctive, butterscotch coat color (Zheng et al., 1999a). Different combinations of drug selection, or orientation of loxP sites can be used effectively to create different types of rearrangements. Creating a large-scale chromosome alteration requires gene targeting in ES cells with $5^{\prime}$ and $3^{\prime}$ loxP cassettes separately. Mice generated through germ line transmission of the manipulated ES cell genome are identified and interbred. The anticipated chromosome rearrangement is then simply identified by following the inheritance of the coat-color pattern. A number of applications of chromosome engineering are reviewed elsewhere (Mills and Bradley, 2001; Yu and Bradley, 2001). Using these strategies, many mouse models resembling human chromosomal rearrangements have been created (Lindsay et al., 1999; Tsai et al., 1999; Lindsay et al., 2001).

Another aspect of chromosome engineering based on Cre/loxP technology is the generation of balancer chromosomes (Zheng et al., 1999b). When two loxP sites are in the opposite orientation, Cre catalyzes the inversion of the intervening DNA fragment (up to $20-30 \mathrm{cM}$ ). This inversion prevents recombination along the length of the chromosome. Thus, inversions can be used to maintain the genomic integrity of a region. These inversions can be designed to function as a balance chromosome by tagging it with a recessive lethal gene. A coat color marker can be added to the inversion chromosome to follow its inheritance in the progeny. The balancer chromosomes are used in large scale ethylnitrosourea (ENU) mutatagenesis strategies, where lethal mutations are screened against a balancer chromosome, for maintenance, mapping and characterization of new mutations (Justice, 2000). In conclusion, recombination based methods have invigorated gene transfer technologies. Most of these methods are at the early stages of development, with their potential yet to be fully exploited.

\section{Functional Analysis}

Owing to genetic resources and a range of methods continuously being developed to manipulate the mouse genome, the laboratory mouse has emerged as a preeminent model for analyzing gene function in the whole organism. In vitro studies, homology based sequence comparisons, and use of invertebrate model systems have successfully identified gene functions. However, there is an increased realization that manipulating genes directly in the mouse is essential for developing models relevant to human physiology and pathology. For these reasons, mouse models will continue to occupy a central position in the analysis of gene function in the post-genomic era.

The genetic approach to ascertain the function of a gene involves creating gain- and loss-of function mutations. These strategies result in opposing phenotypes; permit complementation tests and establish relationships among various genes and their products, thus ordering the sequence of interactions that constitute a genetic pathway. This classical genetic approach has been successfully employed in microbial, plant and invertebrate systems. Although these tenets have not been rigorously adhered to in the mouse system, the technological advances described above will facilitate intense investigations of mouse genetics in the coming decades. An overview of approaches to functional analysis in mouse is given below.

\section{Gain-of-Function Studies}

A gain of function mutation is created by expressing extra copies of the gene of interest in transgenic mice. Changes in the level of gene expression can be achieved within its normal spatiotemporal domain when the gene's expression is directed by its own regulatory region. Alternatively, the expression of the transgene can be achieved at ectopic sites with altered temporal sequence, when its expression is directed by heterologous regulatory elements. Conditional expression of the transgene can be achieved by a number of strategies including induction and recombinase systems, described in the preceeding sections. Early examples of gain of function mutations include expression of a growth hormone gene under the control of the metal-inducible, metallothionein promoter (Palmiter et al., 1982). Transgenic mice fed with zinc showed dramatic growth. Currently, there is a large amount of literature on such studies, impacting every field of modern biology including developmental biology, neurobiology and immunology. Models created by these studies have provided critical information on gene function and identified their relevance to many human and animal diseases and abnormalities.

A major concern regarding gain-of-function mutation studies is that the expression of the transgene is subject to chromosomal influences at the site of integration. The chromatin environment in which the transgene randomly inserts is critical in determining the level of expression. Location of the transgene in heterochromatin or in nuclear compartments where transcription is silenced results in a lack of transgene expression. In contrast, location of the transgene in euchromatin or in the nuclear compartment where active transcription is sustained results in expression of the transgene (Gordon, 1993; Jasin et al., 1996). Furthermore, transgene expression is often copy-number independent, suggesting the significance of the local chromatin environment. Transgene expression is also influenced by cis-acting sequences located in the vicinity of the transgene integration site. This often results in transgene expression at unexpected spatial regions and/ or temporal alterations of expression.

Further understanding of factors influencing transgene transcriptional activity is critical for improving methods by 
which consistent transgene expression can be obtained. Characterization of boundary elements, insulators, and silencers will contribute towards the better transgene design (Sun and Elgin, 1999; Francastel et al., 1999). Locus control regions (LCR), the presence of strong enhancers or nuclear matrix attachment sequences (MARS) can direct the formation of a transcriptionally active domain (Grosveld et al., 1987; Cockell et al., 1999). Sequences, which can direct position-independent, copy-number dependent expression in multiple tissues, have recently been identified (Grosveld et al., 1987; Krempen et al., 1999; Blom van Assendelft et al., 1989; Shewchuk et al., 1999; Talbot et al., 1994, Willoughby et al., 2000). However, these sequences have not yet been incorporated into a general strategy for designing transgenes. Alternatively, one can target the transgene to pre-selected sites via the cell-mediated transgenesis approach (Bronson et al., 1996). Strategies can be designed to specifically integrate a single copy of the transgene at a given site by homologous recombination in ES cells. These targeted cells can then be used to generate transgenic mice.

A second problem related to achieving proper transgenic expression is that the regulatory elements could be scattered and/or at a distance from the coding regions of the gene. With the advent of large-insert cloning vehicles and recombination based cloning and modification systems, it has been possible to achieve accurate expression of the transgene by including larger fragments of DNA in the transgene. Large-insert transgenics are less likely to be influenced by local enhancers and in many instances show copy-dependent gene expression. Faithful, copy-dependent expression of the transgene has been demonstrated for tyrosinase (250kb), myf5 (680kb), Igf2 and $\mathrm{H} 19$ genes $(130 \mathrm{~Kb})$ where small insert transgenics for the same genes had previously failed to recapitulate several aspects of endogenous gene expression and regulation (Schedl et al., 1993; Ainscough et al., 1997; Zweigerdt et al., 1997). Large-insert transgenics have allowed examination of dosage effect in mice. Gene dosage can provide useful information about the function of gene. Large-insert transgenic studies have led to the examination of dosage effect of minibrain gene in learning defects associated with the Down's syndrome (Smith et al., 1997). A BAC transgenic mouse overexpressing Zipro1 discerned its role in proliferation of granule cells in the developing cerebellum, where gene targeting studies had earlier revealed no detectable phenotype for the gene (Yang et al., 1999). These recent developments have now established the importance of gain-of-function mutations towards our understanding of gene function.

\section{Loss-of-Function Studies}

Both gene targeting and transgenic methods create lossof-function mutations. Gene targeting techniques have revolutionized our ability to create a variety of defined mutations in a gene, ranging from subtle mutations and chromosomal rearrangements to tissue specific inducible gene inactivation. Over 7,000 gene knockouts have been described in the literature (Capecchi, 2001). The evergrowing list of mouse mutants generated by gene targeting technology can be accessed on the web (http:// www.jax.org/resources/documents/imr). Many of the problems associated with gene targeting strategies in interpreting phenotypes have been discussed elsewhere (Muller, 1999). Gene targeting has undoubtedly provided many insights into gene function at the level of the whole organism. One of the early realizations was that the same gene may perform multiple functions at different stages of the development of an organism. Initial frustrations with the inability to analyze adult functions of genes whose mutations result in an early embryonic lethality led to the development of the conditional, tissue specific and inducible knockout strategies described in the previous section. Introducing different types of mutations by gene targeting provides different aspects of gene function. Multiple targeting strategies have been particularly useful in analyzing complex phenotypes. For example, a null mutation in NMDA receptors led to perinatal death, which prevented the study of their role in the adult central nervous system (Forrest et al., 1994). A hypomorphic allele generated by disrupting one of the introns of the NMDA receptor resulted in reduced expression of the protein rather than no protein as in the null. This condition in turn manifested itself in a behavioral phenotype similar to schizophrenia in the mutant mice (Mohn et al., 1999). Additionally, a conditional knockout of the NMDA receptor in the subregions of the hippocampus resulted in a mouse with deficiencies in learning behavior (Rampon et al., 2000).

Gene targeting studies also revealed remarkable genetic compensation and developmental plasticity in the mouse. Null mutations in a number of genes often resulted in very minor or the absence of detectable phenotypes, invoking the possibility that other members of the gene family may functionally compensate for the mutated gene. A comparison of single and combined mutations in the gene families provided information on overlapping function and specialized roles of each member of the gene family. Synergestic interactions among members of the Hox gene family have been demonstrated in many studies. For example, mutations in paralogous Hoxa4, Hoxb4 and Hoxd4 genes individually result in varying degrees of vertebral transformations. Different double mutations showed different degrees of synergism whereas triple mutation resulted in a much larger transformation of the vertebral column, demonstrating cooperative interactions between the family members, not revealed by individual mutations (Horan et al., 1995). Compound mutations often reveal unexpected functions for the genes, for instance, a role for Hox genes in mammary gland development became evident only in the mouse carrying triple mutations in the paralogous Hoxa9, Hoxb9 and Hoxd9 genes (Chen and Capecchi, 1999).

Besides creating mutations in the coding regions of the gene, gene targeting has also been used to create mutations in cis-acting elements to determine the role of regulatory elements in the control of gene expression. The significance of relative position among genes and cis-acting elements within the gene clusters has been examined for Hox complex and globin gene clusters. These studies have revealed many features of gene cluster organization including enhancer sharing, competition and locus control regions (Dupe et al., 1997; Kondo and Duboule, 1999; 
Tanimoto et al., 1999; Kmita et al., 2000; Bender et al., 2001; Spitz et al., 2001).

Loss-of-function experiments are carried out in transgenic mice by directing the expression of dominant negative variants, antisense or ribozymes to specific tissues at desired stages of development. Among these, dominant negative mutations have become a powerful alternative to gene knockout studies. The importance of dominant negative mutations was elegantly outlined by Herskowitz (1987). Dominant negative, as the name suggests, is a dominant phenotype, which can be studied, in heterozygous conditions. The basic strategy involves the inhibition of a wild-type gene product by an overproduced mutated variant of the same product. The variant is designed to contain functional subsets of the domains of the parent protein, but either defective or missing in a subset of domains. An overproduced variant forms nonfunctional complexes with the wild-type protein and some of its targets resulting in inhibition of a specific function. For example, dominant negative variants can be designed to inactivate recognition, conduction or amplification in a signal transduction pathway. These mutants can probe various functions within a protein complex, thus exploring the relationships between each protein (Perlmutter and Alberola-Ila, 1996; Yuen, 1999). Similarly, dominant negative variants can be designed to disrupt protein-protein interactions, DNA-binding or transcriptional activation. Although dominant negative variants can be designed based on biochemical or structural information, how these variants function in a complex cellular environment is often unpredictable. An additional problem lies in identifying promoters that are functional in the same cells as the wildtype gene, but achieve higher levels of variant expression. In spite of these limitations, transgenic mice derived from dominant negative variants have provided useful information on gene function.

The use of antisense RNA strategy to generate loss of function in transgenic mice has recently been reviewed (Erickson, 1999). Antisense strategy involves the design of complementary oligonucleotides that hybridize with the $5^{\prime}$ region of the mRNA, thereby inhibiting its translation. Although antisense methods have been successful in plants, fewer published reports are available in transgenic mice. It is believed that antisense expression must be at least 10-20 fold greater than the specific mRNA to inhibit translation. Use of heterologous promoters and design of transgenes, which encode longer antisense RNA are believed to improve the efficiency of inactivating genes in transgenic mice.

Ribozymes, sequence specific endoribonucleases, have great potential to create loss-of-function by cleaving specific RNA molecules. Ribozymes have been successfully used to target and destroy specific viral and cellular RNAs. They are regarded as an important therapeutic tool as antiviral agents. Several studies have used ribozymes in transgenic mice to knockdown the expression of specific target genes (Welch et al., 1998). Two types of ribozymes, hairpin and hammerhead ribozymes, which have specific nucleotide cleavage sites, have been employed in these studies. Although many in vitro studies have shown that ribozymes are effective tools in reducing or eliminating gene expression, their application in transgenic mice is somewhat limited. Examples of ribozyme transgenics include $\beta-2$ microblobulin, glucokinase, $\alpha$-lactalbumin, growth hormone, amelogenin, and HIV-1 among others (L'Huillier et al., 1996; Alami et al., 1999; Andang et al., 1999; Luyckx et al., 1999; Thomas et al., 2001). Lack of toxicity and relatively unique specificity make ribozymes a very attractive tool for transgenesis. Transgenic models are perceived as rapid and inexpensive mouse models to study and evaluate ribozymes for their potential as gene therapeutic agents.

\section{Genetic Complementation}

Genetic complementation is considered the ultimate proof for function of a gene. This involves introduction of a functional gene in mutant mice that results in the reversion of the phenotype. Both large-insert transgenics and gene targeting methods have been employed in complementation analysis. Many examples of the rescue of a classical mutation in mice exist. For instance, a $250 \mathrm{~Kb}$ YAC containing the tyrosinase gene faithfully rescued the albino phenotype in a dosage dependent manner (Schedl et al., 1993). A $670 \mathrm{~kb}$ YAC containing the human HPRT locus complements an HPRT mutation in the mouse (Jakobovits et al., 1993). A 140Kb BAC containing the wild type Clock gene rescued the loss of circadian rhythm in Clock mutant mice (Antoch et al., 1997). Complementation by large-insert transgenics is expected to develop into a valuable resource, particularly in conjunction with the largescale deletions being generated by the previously described chromosome engineering techniques. Recombinogenic targeted modification methods that allow introduction of subtle mutations in the large-inserts will be analyzed in complementation assays to test whether the introduced changes can rescue the mutant phenotype. These types of studies will link both naturally occurring and experimentally induced mutations to observed phenotypes.

Complementation has been tested by gene targeting methods, especially to examine functional compensation of related genes. This strategy commonly referred to as 'knock-in' uses Cre/loxP technology to replace one gene/ domain with another. For example, basic helix-loop-helix transcription factors including $M y f 5, M y o D$, myogenin and MRF4 play important roles in skeletal muscle development. But, they are expressed at different times during embryonic development and mice carrying mutations in these genes have different phenotypes. Mutation in the Myf5 results in defective rib cage formation. Myogenin cDNA was knockedin the Myf5 locus by homologous recombination, which simultaneously disrupted Myf5 function. However, a myogenin knock-in mouse had normal rib cage formation, suggesting functional compensation of myogenin for Myf5's role in rib formation (Wang et al., 1996). Subsequent studies showed that myogenin can substitute for Myf5 in promoting myogenesis with somewhat reduced efficiency (Wang and Jaenisch, 1997). Thus, some aspects of myogenesis may be unique to a given myogenic factor while related factors may share overlapping functions in specific pathways.

Knock-in strategies can be very useful in determining redundant and distinctive roles played by genes involved 
in a specific pathway. For instance, c-Fos and Fra-1 genes are related proteins and are components of the transcription factor AP-1 complex. The two proteins show high homology in their leucine zipper and DNA binding domains and are expressed in partially overlapping domains during mouse development. Knock-in of the Fra-1 in place of $c$-Fos revealed that Fra-1 rescues many c-Fos dependent functions such as bone cell differentiation. But, Fra-1 fails to compensate for $c$-Fos in inducing expression of target genes in fibroblasts (Fleischmann et al., 2000). Knock-in experiments can also provide significant insights on structural relationships among evolutionarily related genes. For example, both Drosophila engrailed and mouse En-2 genes when knocked-in the En-1 locus rescue the En-1 phenotype in the central nervous system, but fail to affect the limb phenotype (Hanks et al., 1995; 1998). Knock-in of Hoxd3 into the paralogous Hoxa3 locus rescues the Hoxa3 phenotype (Greer et al., 2000). These types of complementation studies assist in defining the functional domains of the gene under study and provide information on compensatory functions among potentially related proteins.

\section{Transcriptional Regulation}

Many of the studies described above require an understanding of the transcriptional regulation of developmental and tissue-specific genes. Transgenic mice provide a reliable system for mapping regulatory elements that control spatial and temporal patterns of gene expression (MacDonald and Swift, 1998; Shashikant and Ruddle, 2001). Mapping of regulatory elements that direct tissue specific expression in a developmentally regulated pattern is critical for understanding gene function. These studies establish regulatory pathways that underlie tissue differentiation and provide powerful tools to manipulate developmental processes. A collection of regulatory sequences, with distinct spatial and temporal specificity will be a valuable biological resource. By careful deletion and mutation analysis, it is possible to engineer regulatory sequences that direct gene expression with exquisite specificity.

Cis-regulatory elements are generally identified by reporter gene analysis in transgenic mice (Cui et al., 1994; Gilthorpe and Rigby, 1999). The bacterial $\beta$-galactosidase gene is the most commonly used reporter, as its expression can be visualized by staining tissues with X-gal. Recently the gene encoding green fluorescent protein (GFP) has been engineered for use in transgenic mice (Ikawa et al., 1998). Fluorescence allows detection of the reporter gene expression by non-invasive methods. Another reporter gene in use is human alkaline phosphatase. Bicistronic reporter gene constructs containing two reporter genes are also available (Li et al., 1997). Typically, a reporter gene is inserted in frame with the coding sequence of the transgene that also contains the flanking genomic regions. Alternatively, fragments of DNA surrounding the gene can be cloned upstream of a heterologous promoter, for instance, the mouse heat shock protein 68 ( $h s p 68$ ) promoter, driving a reporter gene (Kothary et al., 1989). Besides their use in cis-regulatory analysis, reporter genes are often inserted in the coding regions in gene targeting experiments to follow the fate of cells in knockout mice. Additionally, reporter genes are now widely used for cell lineage analysis (Spergel et al., 2001).

A confounding problem in regulatory analysis is that the cis-acting elements may be scattered over large distances within the genomic loci. Sequence comparisons and computational programs, so effective in identifying coding regions and functional domains of proteins, are at present ineffective in unequivocally identifying regulatory motifs. Cis-acting elements are orientation-independent and tolerate sequence degeneracy. Thus, no significant guiding principles based on sequence analysis have emerged. Comparative sequencing and phylogenetic distance based analysis of non-coding, regulatory regions are just emerging (Kim et al., 2000; Hardison, 2000; Sumiyama et al., 2001).

Although cis-regulatory elements may be scattered over large distances, the first place to look is in the immediate vicinity of the gene. Typically, several kb of DNA immediately upstream of the translation start sites are examined for regulatory sequences. If the functional elements are not identified in these regions, the next step is to include larger 5' and 3' DNA fragments and all introns for analysis. To identify regulatory elements acting at considerable distance, reporter genes are inserted in the coding regions of large-inserts by recombinogenic targeting methods and the large reporter gene constructs generated are analyzed in transgenic mice (Chiu et al., 2000; Carvajal et al., 2001; John et al., 2001; Reizis and Leder, 2001).

Cis-regulatory regions for a large number of developmentally regulated and tissue-specific genes have now been characterized. DNA fragments as small as 100$200 \mathrm{bp}$ are known to confer reproducible, spatiotemporal patterns of gene expression to the reporter genes in transgenic mice (Shashikant et al., 1995; MacDonald and Swift, 1998). These compact enhancer regions are often multi-component, partially redundant and interdependent, similar to those characterized for viral enhancers in cell transfection systems. In many instances, mutational analyses have defined critical nucleotide sequences essential for the enhancer activities. The identification of the critical sequence has often led to the candidate transcription factors regulating the enhancer activities (Sham et al., 1993). Interactions between the transcription factor and cis-acting elements are confirmed by either gainof-function or gene targeting type experiments thereby establishing components of the regulatory pathways involved in specific developmental processes.

Transgenic analyses of cis-acting elements combined with sequence comparisons of regulatory regions among diverse species are providing many evolutionary insights. Genomic regions with a high degree of conservation provide candidates for cis-acting elements that can be examined in transgenic mice (Marshall et al., 1994; Aparacio et al., 1995; Morrison et al., 1995). A comparison of non-coding sequence between distant species has often led to the identification of critical elements controlling tissuespecific gene expressions. In contrast, a careful comparison of well-defined enhancer sequences among different vertebrate species has led to identification of subtle variations that could be correlated with changes in gene 
expression and phenotype (Shashikant et al., 1998b). These studies are focusing on variations in regulatory regions as the basis for evolution of diverged morphologies among vertebrates. The role of well-defined compact enhancers in mouse development is also examined by gene targeting methods. Deletion or mutation of the enhancer region or its replacement with heterospecific enhancers have been performed to assess the contribution of specific enhancer elements to the expression of the gene and its subsequent phenotype (Gerard et al., 1997; McDevitt et al 1997). Both reporter gene analysis and recombinogenic targeting methods have been employed in analyzing regulatory constraints that are critical for clustered gene organizations. For example, long range cis effects affecting larger regions of chromosomes, such as $X$-chromosome inactivation, have been delimited to specific DNA fragments (Lee and Jaenisch, 1997). In summary, the combined use of large-insert transgenics and recombinogenic targeting methods will make regulatory analysis much more rapid and efficient in the near future.

\section{Imprinting and Reprogramming}

The phenomenon of imprinting was discovered by nuclear transplantation experiments described in an earlier section. Imprinting provides mammalian development with an additional layer of epigenetic control. Imprinted genes regulate critical aspects of development including placentation, growth, energy metabolism, lactation and behavior (Solter, 1998; Surani, 2001; Ferguson-Smith and Surani, 2001). To date, about 45 imprinted genes have been identified (http://www.mgu.har.mrc.ac.uk). Certain genes are differentially modified in paternal and maternal genomes, resulting in repression of the gene expression in respective genomes. Normal development is possible only when the expression of the gene originates from the unmodified genome of the parent. For example, Igf2 is repressed in the maternal genome and active only in the paternal genome (Reik et al., 2000). In contrast, Igf2r is repressed in the paternal genome and active in the maternal genome in the mouse (Schweifer et al., 1997). Imprinted genes are often organized in clusters and the analysis of the imprinting mechanism has revealed several interesting regulatory elements including differential methylation, silencers, boundary elements, and antisense transcripts (Ferguson-Smith and Surani, 2001). These elements ensure monoallelic expression of imprinted genes. Differentially methylated regions (DMRs) are strongly associated with imprinted genes. Thus, imprinting has emerged as an important model for studying epigenetic regulation of mammalian development.

Whatever the mechanism of imprinting is, it should be reversible in order to account for transmission of paternal or maternal imprints to subsequent generations. Implicit in this requirement is the existence of a mechanism for reprogramming of the genome of gametes (Surani, 2001). It appears that the existing imprints are erased by genome wide-demethylation in the primordial germ cells (PGCs). The initiation of new imprints presumably occurs during gametogenesis. The imprinting mark, once set, cannot be reversed during subsequent development, except in PGCs. Imprinting results in epigenetic asymmetry in the parental genomes at fertilization (Reik et al., 2001; Rideout et al., 2001; Surani, 2001).

A comparison of the genome-wide methylation levels indicates that the overall levels of methylation are low in PGCs, but raises during gametogenesis, with sperm DNA becoming more methylated relative to the oocyte. After fertilization, the paternal genome undergoes marked active demethylation while the maternal genome undergoes passive demethylation. By the blastocyst stage, the zygotic genome is hypomethylated. At subsequent stages, global methylation takes place resulting in an apparently uniform pattern of methylation on both parental alleles by gastrulation (Reik et al., 2001; Rideout et al., 2001).

The epigenetic status of the somatic nucleus is remarkably different from that of the gametes. In cloning experiments, the somatic nucleus transplanted into the unfertilized oocyte must undergo epigenetic modifications and reprogramming in order to initiate the entire developmental process. This involves erasure of the existing epigenetic state and initiation of the embryonic gene expression program. Success at cloning suggests that the oocyte has the machinery required for reprogramming the genome. However, the poor efficiency of cloning and occurrence of several abnormalities in cloned animals suggest reprogramming errors (Dean et al., 2001; Humphreys et al., 2001). Insufficient demethylation, precocious remethylation and erasure of imprints are suspected to result in fetal and placental abnormalities. Future improvements in cloning efficiency depends upon our understanding of imprinting and reprogramming events that confer totipotency to the transplanted somatic cell nuclei. With the success of cloning in the mouse, these problems can be readily addressed in this experimental organism. Delineating components of the reprogramming machinery in the oocyte and PGC represents an exciting area of functional analysis.

\section{Applications}

It is clear from the above description that technological innovations, which arose as a result of a desire to manipulate the mouse genome have resulted in fairly sophisticated methods for functional analysis. It is not surprising that these innovations have impacted a diverse field of study with basic, biomedical, and agricultural applications. Some of the significant applications of transgenic technologies are described below.

\section{Finding New Genes: 'Trap Technology'}

Although transgenic and gene targeting methods are aimed at studying the function of known genes, the possibility of identifying unknown genes through these technologies was evident very early on (Zambrowicz and Friedrich, 1998; Stanford et al., 2001). Transgene expression is often influenced by local enhancers. As the integration of a transgene into the mouse genome is random, it was estimated that $5-10 \%$ of transgenes disrupt the function of endogenous genes (Allen et al., 1988; Kothary et al., 1988). In principle, the identification of the disrupted endogenous gene is possible as the transgene provides a molecular tag. However, several technical difficulties including 
rearrangements or deletions induced by the transgene have precluded developing a general strategy for identifying novel genes affecting developmental processes. The idea of trapping genes by random insertion in the genome was further developed in ES cells (Gossler et al., 1989; von Melchner et al., 1989; 1992; Frederich and Soriano, 1991; Korn et al., 1992). The trap vectors, containing reporter genes, can be introduced into ES cells by electroporation or retroviral integration. The expression pattern of the trapped gene is visualized by staining for the reporter gene introduced with the trap vector. The trap vector could be mutagenic and also provide a means to determine the sequence of the trapped gene. ES cell clones where mutation has occurred can be used to generate knockout mice by blastocyst injections followed by germ line transmission and breeding to generate mice that are homozygous for the mutation. The utility of this approach has broad application in the post-genomic era (Zambrowicz et al., 1998).

The trap vectors are of four basic types; enhancer trap, promoter trap, gene trap and polyA trap (Zambrowicz and Friedrich, 1998; Stanford et al., 2001). The enhancer trap vector contains a minimal promoter that is insufficient to activate transcription. When integrated close to enhancers in the genome, the promoter is activated and the reporter gene expression reflects the enhancer that is trapped. Promoter trap vector contains a promoterless reporter or a selectable marker gene, whose activity is dependent upon trapping promoters, by inserting near a promoter or in the exon of an unknown gene. A gene trap vector contains a reporter gene or a selectable marker gene preceded by a splice acceptor. These vectors are expressed when integrated into an intron of an unknown gene, resulting in a fusion transcript containing the $5^{\prime}$ exon(s) of the trapped gene. PolyA trap vectors are a more recent addition to the gene trap methods. Here the expression of the selectable marker gene is under the control of a promoter that is active in the ES cells, but lacks a polyA addition signal. Gene expression is achieved by trapping polyA addition signals at the site of integration near the $3^{\prime}$ end of the trapped gene. Gene trap vectors require that for selection, the trapped genes should be transcriptionally active in the ES cell. In contrast, the polyA trap vectors trap non-expressed genes as well. Special trap strategies can be designed to identify sub-classes of genes of interest. For example, secretory-trap vectors are designed to identify secreted and transmembrane proteins that are expressed in the ES cells, based on the fact that the $\beta$-galactosidase gene activity is abolished in the lumen of the endoplasmic reticulum. Its expression can be assayed only when the signal sequences are acquired by the trap vector resulting in the secretion of the reporter gene (Skarnes et al., 1995). Trap strategies are also employed to identify genes that are expressed in specific differentiation lineages or as a result of induction by external reagents. Libraries of frozen ES cells, each containing a trapped gene and the information on partial sequence of the trapped genes are available (Zambrowicz et al., 1998). With the completion of the mouse genome sequencing projects, the identity of genes mutated in ES cells can be discerned. Mutated ES cells can be used to generate mice for the assessment of function of the trapped gene. Thus trap technology has emerged as a high-throughput random mutagenesis approach in the mouse that promises to simultaneously facilitate the identification of new genes, the study of gene expression pattern and the phenotypic analyses.

\section{Stem Cells and Therapeutic Cloning}

The potential of ES cells to differentiate into multiple cell lineages has been known for many years and their use in tissue repair has long been contemplated (Colman and Kind, 2000). Animal cloning by nuclear transfer demonstrated that an adult nucleus can be reprogrammed to produce an entire organism has thrust the field into the forefront (Wilmut et al., 1997). Success at the derivation of the human ES cells has now raised the possibility that ES cells can be derived from individual adult patients, and differentiated into the desired cell types needed for repair of damaged tissues (Thomson et al., 1998). Furthermore, there is an increased realization that adult stem cells isolated from many organs are more plastic than previously thought. Thus, stem cell research and therapeutic cloning have emerged as new frontiers of biological research (Colman and Kind, 2000; Fuchs and Segre, 2000; Thomson and Odorico, 2000; Blau et al., 2001; Lovell-Badge, 2001; Donovan and Gearhart, 2001; Spradling et al., 2001; Reya et al., 2001; Temple, 2001; Bianco and Robey, 2001).

ES cells when injected into a blastocyst contribute to all the tissues of the chimeric mouse. In culture, ES cells are maintained in an undifferentiated state in the presence of the cytokine, leukemia inhibitory factor (LIF; Smith and Hooper 1987; Smith et al., 1988; Williams et al., 1988). When LIF is withdrawn, ES cells aggregate into embryoid bodies, where they differentiate into a variety of cell lineages (Bradley, 1990; Fuchs and Segre, 2000). Different combinations of growth factors direct embryoid bodies to different cell types including adipocytes, erythrocytes, macrophages, vascular smooth muscle cells, oligodendrocytes or astrocytes. With more than 2000 growth factors now cloned or purified, there is tremendous potential to employ growth factor supplements to direct ES cells to differentiate into specific cell lineages. Studies using mouse ES cells provide the necessary groundwork for differentiating human ES cells into diverse cell lineages for future clinical applications (Fuchs and Segre, 2000; Colman and Kind, 2000; Thomson and Odorico, 2000; Donovan and Gearhart, 2001).

The existence of stem cells in adult tissues for the purpose of maintenance of tissue homeostasis has long been known (Fuchs and Segre, 2000; Spradling et al., 2001; Temple, 2001). These are slow-cycling cells, few in number that occupy specific niches within adult organs and are capable of self-renewal and differentiation. Adult stem cells were viewed as restricted in their differentiation capacity and able to regenerate only those cell types for the organ where they were resident. However, the realization that adult stem cells are much more pliable and capable of differentiating into a variety of tissues is more recent (Blau et al., 2001). For example, bone marrow derived cells besides contributing to the blood also contribute to muscle, brain, liver, heart, and the vascular endothelium (Ferrari et al., 1998; Gussoni et al., 1999; 
Brazelton et al., 2000; Mezey et al., 2000). Neuronal cells can give rise to blood and muscle tissue (Bjornson et al., 1999; Galli et al., 2000). Skin stem cells can make neurons, glia, smooth muscle and adipocytes (Toma et al., 2001). These studies are rapidly changing the traditional views of adult stem cells. With the current controversy regarding the human embryonic stem cells, adult stem cells are an attractive alternative for clinical applications.

Stem cell potential for repairing tissue injury or curing diseases has been demonstrated in animal models. For example, mouse ES cells differentiated in vitro into cardiomyocytes function in intracardiac grafts in mice (Klug et al., 1996). Mouse ES cells derived from glial precursor cells transplanted into a rat with myelin disease, produced myelin in the brain and spinal cord (Brustle et al., 1999). Many stem cell based tissue engineering projects, including bone, skin, cornea and nervous tissues are now under clinical trials (Colman and Kind, 2000). Stem cell based therapies have been envisioned for many neurological diseases including Parkinson's disease, Huntington's disease, multiple sclerosis and for repairing spinal cord injuries (Temple, 2001). Use of stem cells in producing artificial organs by tissue engineering is a newly emerging field (Bianco and Robey, 2001).

\section{Models for Human Diseases}

The development of gene transfer technologies for manipulating the genome has considerably enhanced our ability to create experimental models for studying human pathology. Among experimental organisms, the mouse has emerged as a pre-eminent model system for human diseases. The mouse is the experimental organism of choice to generate models for human disorders and abnormalities. No other experimental organism can be manipulated in as many different ways and mouse physiology closely resembles that of human. Recent progress has led to the identification of mouse genes responsible for many naturally occurring disorders, in parallel with mouse models that are being developed by transgenic and gene targeting methods. The number of mouse models available for the study of human genetic disorders and diseases is large and it is a difficult task to produce here a comprehensive list of available models. Mouse models for human diseases can be searched in Mouse Genome Databases and salient features of these models have been reviewed elsewhere (Bedell et al., 1997a,b). The initial studies focused on producing mouse models of monogenic human diseases including LeschNyhan Syndrome, Gaucher's disease and cystic fibrosis (Kuehn et al., 1987; Engle et al., 1996; Tybulewicz et al., 1992; Snouwaert et al., 1992).

The newly emerging chromosome engineering technology promises to generate more complex mouse models with chromosomal rearrangements including deletions, duplications and translocations (Yu and Bradley, 2001; Lindsay et al., 1999; Tsai et al., 1999; Lindsay et al., 2001). Chromosomal abnormalities are a principal cause of many human diseases that produce early abortions and profound developmental disabilities. Translocations are prevalent in many human cancers including leukaemia, lymphoma and sarcoma. Translocations engineered in the mouse could serve as better models for human leukamia (Buchholz et al., 2000, Collins et al., 2000). Chromosomal deletion of $1.5 \mathrm{Mb}$ DNA fragment in mice corresponding to human 22q11 results in cardiovascular defects similar to those observed in DiGeorge syndrome (Merscher et al., 2001).

Chromosome engineering and large-insert transgenic methodologies are likely to be increasingly used in the characterization of polygenic diseases. A number of diseases including diabetes, cancer, epilepsy, bipolar disorder, asthma, and obesity are caused by cumulative effects of mutations at multiple genes. The interactions of genes that cause such complex diseases are called quantitative trait loci (QTL). Although many QTL have been discovered, few causative genes have been identified. One example is the analysis of asthma QTL in transgenic mice (Symula et al., 1999). In this study, a panel of YAC's covering $1 \mathrm{Mb}$ intervals of human chromosome $5 \mathrm{q} 31$. This region contains 6 cytokine genes and 17 partially characterized genes. Each YAC was used to generate transgenic lines that were analyzed for asthma-associated phenotypes. Functional analysis of QTL is perhaps the next major area of application for transgenic technologies in the mouse.

Gene transfer technology will affect human disease treatment in the clinic using gene therapy applications. There are many ongoing clinical trials aimed at alleviating disease by replacing the missing gene product. These studies suffer from inefficient gene delivery vectors that fail to initiate therapeutic levels of gene product, may not be targeted to a specific tissue, or are only active at therapeutic levels for limited periods of time. While these approaches may be supplanted by therapeutic cloning technologies, they likely will find use in cancer treatment paradigms where cancerous tissue is specifically targeted for toxic therapies.

\section{Animal Biotechnology}

With the dramatic demonstration of the power of growth hormone transgenics in mice, biotechnological aspirations for creating heavily muscled and lower fat cattle and other livestock became an immediate goal for many laboratories and private companies (Palmiter et al., 1982; Pursel et al., 1989; Ebert, 1998;Ward and Brown, 1998; Murray, 1999; Niemann and Kues, 2000). Improvements in many economically important traits of livestock including rate of weight gain, milk yield and composition, wool characteristics and egg-laying frequency, have been achieved by hundreds of years of painstakingly slow, yet successful selective animal breeding. The potential for transgenic technology to accelerate selection in livestock is great. However, a number of problems associated with the transgenic technology aimed at improving genetic potential have significantly reduced commercial applications in the agricultural industries. The process of pronuclear injection is less efficient in domestic animals than in mice. Some of the problems of the mouse transgenics, such as variability of success at achieving high levels of gene expression, pose even greater barriers for generating successful transgenic domestic animals. The costs are compounded when considering their longer 
generation interval and smaller litter size.

The first transgenic sheep and pigs expressing human growth hormone under the control of metallothionein promoter were reported in 1985 (Hammer et al., 1985). The growth hormone and related genes represent the largest class of transgenes transferred into livestock with the aim of altering body composition. Achieving a controlled regulation of growth hormone genes in livestock has been a challenge. In general, pigs and sheep expressing growth hormone genes have been leaner and consume less feed per weight gain, but they suffer from a number of complications as a result of the high, unregulated levels of circulating growth hormone. Growth hormone transgenics are vigorously pursued in many commercial fisheries in about 35 species including salmon, catfish and tilapia. One example is the transgenic salmon generated by the injection of the salmon growth hormone gene under the control of the ocean pout antifreeze protein promoter. The transgenic salmon grow most rapidly during their first year and reach market size a year earlier than commercially grown nontransgenic salmon (Hew et al., 1995). A number of concerns regarding transgenic fish including consumer acceptance and ecological risks to naturally occurring fish remain to be addressed (Muir and Howard, 1999).

Besides growth hormone transgenics, other examples aimed at improving genetic potential of agricultural animals include transgenic pigs expressing insulin-like growth factor 1 (IGF-1) under the control of an avian skeletal $\alpha$-actin promoter, resulting in enhanced growth and body composition traits (Pursel et al., 1990). Overexpression of IGF-1 in hair follicles in sheep resulted in 17\% increase in wool growth at the first shearing in the first generation. For unknown reasons, no further increase in wool growth was observed at subsequent shearing or in the second generation offspring (Damak et al.,1996; Su et al., 1998). Transgenic pigs expressing bacterial phytase under the control of the mouse parotid secretary protein promoter were shown to secrete phytase in saliva (Golovan et al., 2001). Salivary phytase was shown to facilitate greater digestion of dietary phytate phosphorus, and reduce the requirement for inorganic phosphate supplements in feeding and reduce fecal phosphorus output by up to $75 \%$. These pigs offer a unique approach to the management of phosphorus nutrition and nutrient run-off pollution a very significant problem for the pork industry.

One area of livestock transgenics that can be found in various phases of commercial development is 'pharming', which refers to the production of pharmaceuticals in milk (Clark 1998; Rudolph, 1999). Promoters of genes that are expressed in mammary glands such as $\alpha$-, and $\beta$-caseins, $\beta$-lactoglobulin from several species are used to drive the expression of a transgene for a therapeutic protein to the mammary glands of sheep, goats, cattle, rabbits and pigs. Proteins produced in their milk, often in large quantity undergo appropriate post-translational modifications and retain high biological activities. At least 17 different proteins are produced in five different livestock that include $\alpha-$ antitrypsin, clotting factor VIII, anti-thrombin III and erythopoeitin for kidney dialysis patients. Many of the recombinant proteins produced in milk are now under different phases of clinical trial. This approach may be more economical than large cell fermentation system when producing therapeutic proteins for medical use (Rudolph, 1999).

Another area of biomedical application of transgenic technology is the production of transgenic animals for xenotransplantation (French et al., 1998; Niemann and Kues, 2000). Transgenic pigs expressing human complement regulatory genes have been generated in an effort to overcome hyper acute rejection response (Cozzi and White, 1995). Such transgenic pigs are likely to be used in xenotransplantation to overcome acute shortage of allogenic organs. Using cloning and gene targeting technologies to produce small swine without the enzymes required to display glycosylated peptides that contribute to organ rejection are also under evaluation (Lai et al., 2002). It remains to be seen whether these approaches will achieve their implied benefit since xenotransplanation must be shown to be free from transferring viral disease across species barriers.

Many of the shortcomings of transgenic technologies in non-mouse species are now overcome by cloning. In contrast to the slow application of transgenic technology to agriculture, cloning of animals is already having a discernible impact on agricultural industries. The ability to use a cell-based screening system for expression of the transgene prior to generating genetically modified organisms (GMOs) has resolved a major issue of transgene expression. Fetal sheep fibroblasts were transfected with human clotting factor IX under the control of the sheep $\beta$ lactoglobulin promoter. Nuclei from transfected cells that express the transgene were used to clone sheep by nuclear transfer and the resulting adult ewes secreted factor IX in their milk (Schnieke et al., 1997). The cell-based route for transgenesis via nuclear cloning will replace the tedious pronuclear method of producing transgenic livestock. Nuclear cloning is also providing a method for gene targeting in livestock. Until recently, gene targeting was possible only in the mouse because embryonic stem cells in other species were unavailable. However, gene targeting can now be performed in cultured cells and their nuclei can be used to generate knockout animals (McCreath et al., 2000; Denning et al., 2001; Lai et al., 2002). Besides generating transgenic and gene-targeted livestock, the main application of cloning appears to be in extending genetic gains achieved by conventional breeding. Most production traits in livestock are controlled by a relatively large set of genes that have been selected for by planned breeding schemes or sire selection. Cloning offers a direct method to quickly reproduce elite individual animals without diluting their genetic makeup. Another application of cloning that has caught our imagination are attempts to clone endangered species (Loi et al., 2001; Vogel, 2001). Where breeding in captivity has failed, cloning offers an alternative to preserve biodiversity. Nuclei isolated from Gaur and mouflons when transplanted into enucleated eggs of cows and sheep respectively resulted in live births of the endangered animals. Cell banks could be established to preserve diverse germplasm for future cloning of animals when the need arises. 


\section{Impact of Genome Sequencing Projects}

Transgenic, gene targeting, cloning and stem cell technologies developed during the last two decades have set the stage for mammalian genetics to dominate future decades. The human genome sequencing project in its conception and execution has provided a playing field for mammalian genetics to fulfill this prophecy. The human genome comprises at least 30,000 genes. Biological functions for only a small fraction of these genes are known. While a variety of computational and expression profiling methods have provided valuable insights into the functions of these genes, the necessity of validating these predictions in experimental organisms is now fully appreciated.

The study of gene function, as discussed in this review, involves creating a variety of modifications in genes and their regulatory elements and assessing the phenotypic effect of these engineered modifications. The pre-eminence of the mouse models for studying the monogenic and polygenic basis of complex human physiology and behavior is well appreciated. Gone are the days when mammalian experimental systems were considered slow, cumbersome and expensive. Academic, governmental and private research institutes are rapidly expanding infrastructures for creating and maintaining transgenic mice. Mouse genomic resources include a large number of both naturally occurring and experimentally induced mutations, more than 475 inbred lines, congenic and recombinant inbred strains; extensive chromosomal mapping resources, chromosome substitution strains and radiation hybrid transcript maps (Beck et al., 2000; Nadeau et al., 2000; Avner et al., 2001; Cai et al., 2001; Hudson et al., 2001). Large scale mouse mutagenesis projects are underway throughout the world with goals of identifying novel mutations by phenotypedriven approaches (Justice, 2000; Nolan et al., 2000). The Genome Exploration Group at RIKEN, Japan has obtained a large collection of mouse cDNA sequences that are being used for expression profiling and functional annotation (Kawai et al., 2001). Two mouse genome projects, one public and the other private aim to complete the sequence of the only other mammalian genome, besides human (Hamilton and Frankel, 2001).

With the completion of the human genome sequence project, the functional annotation of genes is expected to take advantage of the available resources in the mouse such as synteny maps for putative common functional regions. This comparative mapping approach will be extended to other species based on segments of chromosome homology or evolutionarily conserved regions of genomes. Application of these methods in different species is likely to identify genetic loci in other mammals where genomes sequencing is not yet a priority. Comparative genomic approaches are also expected to reveal functional identity of many genes and potential regulatory regions buried in the noncoding regions of the genome. Progress in these areas is now occurring rapidly and emphasizes the need for developing more sophisticated tools for gene transfer and functional analysis. The past decade saw rapid advances in gene transfer technologies and the future of these and newer technologies remains unlimited.

\section{Acknowledgements}

Literature cited in this review is not comprehensive. Some references are cited as a way of illustration and where possible readers are referred to recent reviews for more extensive accounts. The authors wish to acknowledge Dr. Cindy McKinney for critical reading of the manuscript and Dr. Ron Kensinger for help with the section on animal biotechnology. We thank Allison Carey and Laura Polanec for help with proofreading the manuscript.This work was supported by a faculty start-up fund to CSS and NIH GM09966 to FHR.

\section{References}

Ainscough, J. F., Koide, T., Tada, M., Barton, S., and Surani, M. A. 1997. Imprinting of Igf2 and H19 from a $130 \mathrm{~kb}$ YAC transgene. Development 124: 3621-3632.

Alami, R., Gilman, J. G., Feng, Y. Q., Marmorato, A., Rochlin, I., Suzuka, S. M., Fabry, M. E., Nagel, R. L., and Bouhassira, E. E. 1999. Anti-beta s-ribozyme reduces beta $s$ mRNA levels in transgenic mice: potential application to the gene therapy of sickle cell anemia. Blood Cells Mol. Dis. 25: 110-119.

Albanese, C., Reutens, A. T., Bouzahzah, B., Fu, M., D'Amico, M., Link, T., Nicholson, R., Depinho, R. A., and Pestell, R. G. 2000. Sustained mammary gland-directed, ponasterone A-inducible expression in transgenic mice. FASEB J. 14: 877-884.

Allen, N. D., Cran, D. G., Barton, S. C., Hettle, S., Reik, W., and Surani, M. A. 1988. Transgenes as probes for active chromosomal domains in mouse development. Nature 333: 852-855.

Amaya, E., and Kroll, K. L. 1999. A method for generating transgenic frog embryos. Methods Mol. Biol. 97: 393-414. Andang, M., Hinkula, J., Hotchkiss, G., Larsson, S., Britton, S., Wong-Staal, F., Wahren, B., and Ahrlund-Richter, L. 1999. Dose-response resistance to HIV-1/MuLV pseudotype virus ex vivo in a hairpin ribozyme transgenic mouse model. Proc. Natl. Acad. Sci. USA. 96: 1274912753.

Anderson, D. G., and Kowalczykowski, S. C. 1997. The recombination hot spot chi is a regulatory element that switches the polarity of DNA degradation by the RecBCD enzyme. Genes Dev. 11: 571-581.

Antoch, M. P., Song, E. J., Chang, A. M., Vitaterna, M. H., Zhao, Y., Wilsbacher, L. D., Sangoram, A. M., King, D. P., Pinto, L. H., and Takahashi, J. S. 1997. Functional identification of the mouse circadian Clock gene by transgenic BAC rescue. Cell 89: 655-667.

Aparicio, S., Morrison, A., Gould, A., Gilthorpe, J., Chaudhuri, C., Rigby, P., Krumlauf, R., and Brenner, S. 1995. Detecting conserved regulatory elements with the model genome of the Japanese puffer fish, Fugu rubripes. Proc. Natl. Acad. Sci. USA. 92: 1684-1688.

Arnheiter, H., Skuntz, S., Noteborn, M., Chang, S., and Meier, E. 1990. Transgenic mice with intracellular immunity to influenza virus. Cell 62: 51-61.

Avner, P., Bruls, T., Poras, I., Eley, L., Gas, S., Ruiz, P., Wiles, M. V., Sousa-Nunes, R., Kettleborough, R., Rana, A., Morissette, J., Bentley, L., Goldsworthy, M., Haynes, 
A., Herbert, E., Southam, L., Lehrach, H., Weissenbach, J., Manenti, G., Rodriguez-Tome, P., Beddington, R., Dunwoodie, S., and Cox, R. D. 2001. A radiation hybrid transcript map of the mouse genome. Nat. Genet. 29: 194-200.

Awatramani, R., Soriano, P., Mai, J. J., and Dymecki, S. 2001. An Flp indicator mouse expressing alkaline phosphatase from the ROSA26 locus. Nat. Genet. 29: 257-259.

Baguisi, A., Behboodi, E., Melican, D. T., Pollock, J. S., Destrempes, M. M., Cammuso, C., Williams, J. L., Nims, S. D., Porter, C. A., Midura, P., Palacios, M. J., Ayres, S. L., Denniston, R. S., Hayes, M. L., Ziomek, C. A., Meade, H. M., Godke, R. A., Gavin, W. G., Overstrom, E. W., and Echelard, Y. 1999. Production of goats by somatic cell nuclear transfer. Nat. Biotechnol. 17: 456-461.

Barton, S. C., Surani, M. A., and Norris, M. L. 1984. Role of paternal and maternal genomes in mouse development. Nature 311: 374-376.

Beck, C. W., and Slack, J. M. 2001. An amphibian with ambition: a new role for Xenopus in the 21st century. Genome Biol. 2: 1029.

Beck, J. A., Lloyd, S., Hafezparast, M., Lennon-Pierce, M., Eppig, J. T., Festing, M. F., and Fisher, E. M. 2000. Genealogies of mouse inbred strains. Nat. Genet. 24: 23-25.

Bedell, M. A., Jenkins, N. A., and Copeland, N. G. 1997. Mouse models of human disease. Part I: techniques and resources for genetic analysis in mice. Genes Dev. 11: 1-10.

Bedell, M. A., Largaespada, D. A., Jenkins, N. A., and Copeland, N. G. 1997. Mouse models of human disease. Part II: recent progress and future directions. Genes Dev. 11: 11-43.

Bender, M. A., Roach, J. N., Halow, J., Close, J., Alami, R., Bouhassira, E. E., Groudine, M., and Fiering, S. N. 2001. Targeted deletion of 5'HS1 and 5'HS4 of the beta-globin locus control region reveals additive activity of the DNasel hypersensitive sites. Blood 98: 2022-2027.

Bianco, P., and Robey, P. G. 2001. Stem cells in tissue engineering. Nature 414: 118-121.

Bjornson, C. R., Rietze, R. L., Reynolds, B. A., Magli, M. C., and Vescovi, A. L. 1999. Turning brain into blood: a hematopoietic fate adopted by adult neural stem cells in vivo. Science 283: 534-537.

Blau, H. M., Brazelton, T. R., and Weimann, J. M. 2001. The evolving concept of a stem cell: entity or function? Cell 105: 829-841.

Blom van Assendelft, G., Hanscombe, O., Grosveld, F., and Greaves, D.R. 1989. The beta-globin dominant control region activates homologous and heterologous promoters in a tissue-specific manner. Cell. 56: 969-77.

Bradley, A. 1990. Embryonic stem cells: proliferation and differentiation. Curr. Opin. Cell Biol. 2: 1013-1017.

Bradley, A., Evans, M., Kaufman, M. H., and Robertson, E. 1984. Formation of germ-line chimaeras from embryoderived teratocarcinoma cell lines. Nature 309: 255-256.

Bradshaw, M. S., Bollekens, J. A., and Ruddle, F. H. 1995. A new vector for recombination-based cloning of large DNA fragments from yeast artificial chromosomes. Nucleic Acids Res. 23: 4850-4856.
Bradshaw, M. S., Shashikant, C. S., Belting, H. G., Bollekens, J. A., and Ruddle, F. H. 1996. A long-range regulatory element of $\mathrm{Hoxc} 8$ identified by using the pClasper vector. Proc. Natl. Acad. Sci. USA. 93: 24262430.

Brazelton, T. R., Rossi, F. M., Keshet, G. I., and Blau, H. M. 2000. From marrow to brain: expression of neuronal phenotypes in adult mice. Science 290: 1775-1779.

Brinster, R. L. 1974. The effect of cells transferred into the mouse blastocyst on subsequent development. J. Exp. Med. 140: 1049-1056.

Brinster, R. L. 1998. Embryo culture, stem cells and experimental modification of the embryonic genome. An interview with Professor Ralph Brinster. Interview by Juan Arechaga. Int. J. Dev. Biol. 42: 861-878.

Brinster, R. L., Sandgren, E. P., Behringer, R. R., and Palmiter, R. D. 1989. No simple solution for making transgenic mice [letter; comment]. Cell 59: 239-241.

Bromhall, J. D. 1975. Nuclear transplantation in the rabbit egg. Nature 258: 719-722.

Bronson, S. K., Plaehn, E. G., Kluckman, K. D., Hagaman, J. R., Maeda, N., and Smithies, O. 1996. Single-copy transgenic mice with chosen-site integration [see comments]. Proc. Natl. Acad. Sci. USA. 93: 9067-9072.

Brustle, O., Jones, K. N., Learish, R. D., Karram, K., Choudhary, K., Wiestler, O. D., Duncan, I. D., and McKay, R. D. 1999. Embryonic stem cell-derived glial precursors: a source of myelinating transplants. Science 285: 754756.

Bubeck, P., Winkler, M., and Bautsch, W. 1993. Rapid cloning by homologous recombination in vivo. Nucleic Acids Res. 21: 3601-3602.

Buchholz, F., Refaeli, Y., Trumpp, A., and Bishop, J. M. 2000. Inducible chromosomal translocation of AML1 and ETO genes through Cre/loxP-mediated recombination in the mouse. EMBO Rep. 1: 133-139.

Burke, D. T., Carle, G. F., and Olson, M. V. 1987. Cloning of large segments of exogenous DNA into yeast by means of artificial chromosome vectors. Science 236: 806-812.

Byrne, G. W., and Ruddle, F. H. 1989. Multiplex gene regulation: a two-tiered approach to transgene regulation in transgenic mice. Proc. Natl. Acad. Sci. USA. 86: 54735477.

Cai, W. W., Chow, C. W., Damani, S., Gregory, S. G., Marra, M., and Bradley, A. 2001. An SSLP marker-anchored BAC framework map of the mouse genome. Nat. Genet. 29: 133-134.

Campbell, K. H., McWhir, J., Ritchie, W. A., and Wilmut, I. 1996. Sheep cloned by nuclear transfer from a cultured cell line [see comments]. Nature 380: 64-66.

Capecchi, M. R. 1980. High efficiency transformation by direct microinjection of DNA into cultured mammalian cells. Cell 22: 479-488.

Capecchi, M. R. 2001. Generating mice with targeted mutations. Nat. Med. 7: 1086-1090.

Carvajal, J. J., Cox, D., Summerbell, D., and Rigby, P. W. 2001. A BAC transgenic analysis of the Mrf4/Myf5 locus reveals interdigitated elements that control activation and maintenance of gene expression during muscle development. Development 128: 1857-1868.

Chen, F., and Capecchi, M. R. 1999. Paralogous mouse 
Hoxgenes, Hoxa9, Hoxb9, and Hoxd9, function together to control development of the mammary gland in response to pregnancy. Proc. Natl. Acad. Sci. USA. 96: 541-546.

Chiu, C. H., Amemiya, C. T., Carr, J. L., Bhargava, J., Hwang, J. K., Shashikant, C. S., Ruddle, F. H., and Wagner, G. P. 2000. A recombinogenic targeting method to modify large-inserts for cis-regulatory analysis in transgenic mice: construction and expression of a 100kb, zebrafish Hoxa-11b-lacZ reporter gene. Dev. Genes Evol 210: 105-109.

Cibelli, J. B., Stice, S. L., Golueke, P. J., Kane, J. J., Jerry, J., Blackwell, C., Ponce de Leon, F. A., and Robl, J. M. 1998. Cloned transgenic calves produced from nonquiescent fetal fibroblasts. Science 280: 1256-1258.

Clark, A. J. 1998. The mammary gland as a bioreactor: expression, processing, and production of recombinant proteins. J. Mammary Gland Biol. Neoplasia 3: 337-350.

Cockell, M., and Gasser, S. M. 1999. Nuclear compartments and gene regulation. Curr. Opin. Genet. Dev. 9: 199-205.

Collas, P., Balise, J. J., and Robl, J. M. 1992. Influence of cell cycle stage of the donor nucleus on development of nuclear transplant rabbit embryos. Biol. Reprod. 46: 492500.

Collas, P., and Barnes, F. L. 1994. Nuclear transplantation by microinjection of inner cell mass and granulosa cell nuclei. Mol. Reprod Dev. 38: 264-267.

Collins, E. C., Pannell, R., Simpson, E. M., Forster, A., and Rabbitts, T. H. 2000. Inter-chromosomal recombination of $M I l$ and $A f 9$ genes mediated by cre-loxP in mouse development. EMBO Rep. 1: 127-132.

Colman, A., and Kind, A. 2000. Therapeutic cloning: concepts and practicalities. Trends Biotechnol. 18: 192196.

Copeland, N. G., Jenkins, N. A., and Court, D. L. 2001. Recombineering: a powerful new tool for mouse functional genomics. Nat. Rev. Genet. 2: 769-779.

Cozzi, E., and White, D. J. 1995. The generation of transgenic pigs as potential organ donors for humans. Nat. Med. 1: 964-966.

Cronin, C. A., Gluba, W., and Scrable, H. 2001. The lac operator-repressor system is functional in the mouse. Genes Dev. 15: 1506-1517.

Cui, C., Wani, M. A., Wight, D., Kopchick, J., and Stambrook, P. J. 1994. Reporter genes in transgenic mice. Transgenic Res. 3: 182-194.

Dabert, P., and Smith, G. R. 1997. Gene replacement with linear DNA fragments in wild-type Escherichia coli: enhancement by Chi sites. Genetics 145: 877-889.

Damak, S., Su, H., Jay, N. P., and Bullock, D. W. 1996. Improved wool production in transgenic sheep expressing insulin-like growth factor 1. Biotechnology (N Y) 14: 185188.

Dean, W., Santos, F., Stojkovic, M., Zakhartchenko, V., Walter, J., Wolf, E., and Reik, W. 2001. Conservation of methylation reprogramming in mammalian development: aberrant reprogramming in cloned embryos. Proc. Natl. Acad. Sci. USA. 98: 13734-13738.

Denning, C., Burl, S., Ainslie, A., Bracken, J., Dinnyes, A., Fletcher, J., King, T., Ritchie, M., Ritchie, W. A., Rollo, M., de Sousa, P., Travers, A., Wilmut, I., and Clark, A. J.
2001. Deletion of the alpha $(1,3)$ galactosyl transferase (GGTA1) gene and the prion protein (PrP) gene in sheep. Nat. Biotechnol. 19: 559-562.

Doetschman, T., Gregg, R. G., Maeda, N., Hooper, M. L., Melton, D. W., Thompson, S., and Smithies, O. 1987. Targetted correction of a mutant HPRT gene in mouse embryonic stem cells. Nature 330: 576-578.

Doetschman, T., Maeda, N., and Smithies, O. 1988. Targeted mutation of the Hprt gene in mouse embryonic stem cells. Proc. Natl. Acad. Sci. USA. 85: 8583-8587.

Donovan, P. J., and Gearhart, J. 2001. The end of the beginning for pluripotent stem cells. Nature 414: 92-97.

Dupe, V., Davenne, M., Brocard, J., Dolle, P., Mark, M., Dierich, A., Chambon, P., and Rijli, F. M. 1997. In vivo functional analysis of the Hoxa-1 3' retinoic acid response element (3' RARE). Development 124: 399-410.

Dymecki, S. M., and Tomasiewicz, H. 1998. Using Flprecombinase to characterize expansion of Wnt1expressing neural progenitors in the mouse. Dev. Biol. 201: 57-65.

Ebert, K. M. 1998. The use of transgenic animals in biotechnology. Int. J. Dev. Biol. 42: 1003-1008.

Engle, S. J., Womer, D. E., Davies, P. M., Boivin, G., Sahota, A., Simmonds, H. A., Stambrook, P. J., and Tischfield, J. A. 1996. HPRT-APRT-deficient mice are not a model for lesch-nyhan syndrome. Hum. Mol. Genet. 5: 1607-1610.

Erickson, R. P. 1999. Antisense transgenics in animals. Methods 18: 304-310.

Evans, M. J. 1972. The isolation and properties of a clonal tissue culture strain of pluripotent mouse teratoma cells. J. Embryol. Exp. Morphol. 28: 163-176.

Evans, M. J. 2001. The cultural mouse. Nat. Med. 7: 10811083.

Evans, M. J., Bradley, A., Kuehn, M. R., and Robertson, E. J. 1985. The ability of EK cells to form chimeras after selection of clones in G418 and some observations on the integration of retroviral vector proviral DNA into EK cells. Cold Spring Harb. Symp. Quant. Biol. 50: 685-689.

Evans, M. J., and Kaufman, M. H. 1981. Establishment in culture of pluripotential cells from mouse embryos. Nature 292: 154-156.

Federspiel, M. J., and Hughes, S. H. 1997. Retroviral gene delivery. Methods Cell Biol. 52: 179-214.

Ferguson-Smith, A. C., and Surani, M. A. 2001. Imprinting and the epigenetic asymmetry between parental genomes. Science 293: 1086-1089.

Ferrari, G., Cusella-De Angelis, G., Coletta, M., Paolucci, E., Stornaiuolo, A., Cossu, G., and Mavilio, F. 1998. Muscle regeneration by bone marrow-derived myogenic progenitors. Science 279: 1528-1530.

Fleischmann, A., Hafezi, F., Elliott, C., Reme, C. E., Ruther, U., and Wagner, E. F. 2000. Fra-1 replaces C-Fosdependent functions in mice. Genes Dev. 14: 2695-2700.

Folger, K. R., Thomas, K., and Capecchi, M. R. 1985. Nonreciprocal exchanges of information between DNA duplexes coinjected into mammalian cell nuclei. Mol. Cell Biol. 5: 59-69.

Folger, K. R., Wong, E. A., Wahl, G., and Capecchi, M. R. 1982. Patterns of integration of DNA microinjected into cultured mammalian cells: evidence for homologous 
recombination between injected plasmid DNA molecules. Mol. Cell Biol. 2: 1372-1387.

Forrest, D., Yuzaki, M., Soares, H. D., Ng, L., Luk, D. C., Sheng, M., Stewart, C. L., Morgan, J. I., Connor, J. A., and Curran, T. 1994. Targeted disruption of NMDA receptor 1 gene abolishes NMDA response and results in neonatal death. Neuron 13: 325-338.

Francastel, C., Walters, M. C., Groudine, M., and Martin, D. I. 1999. A functional enhancer suppresses silencing of a transgene and prevents its localization close to centrometric heterochromatin. Cell 99: 259-269.

French, A. J., Greenstein, J. L., Loveland, B. E., and Mountford, P. S. 1998. Current and future prospects for xenotransplantation. Reprod Fertil Dev. 10: 683-696.

Friedmann, T. 1992. A brief history of gene therapy. Nat. Genet. 2: 93-98.

Friedrich, G., and Soriano, P. 1991. Promoter traps in embryonic stem cells: a genetic screen to identify and mutate developmental genes in mice. Genes Dev. 5: 1513-1523.

Fuchs, E., and Segre, J. A. 2000. Stem cells: a new lease on life. Cell 100: 143-155.

Galas, D.J. and McCormack, S.J. 2002. Genomic Technologies: Present and Future. Caister Academic Press, Wymondham, UK.

Galli, R., Borello, U., Gritti, A., Minasi, M. G., Bjornson, C., Coletta, M., Mora, M., De Angelis, M. G., Fiocco, R., Cossu, G., and Vescovi, A. L. 2000. Skeletal myogenic potential of human and mouse neural stem cells. Nat. Neurosci. 3: 986-991.

Gandolfi, F. 2000. Sperm-mediated transgenesis. Theriogenology 53: 127-137.

Gardner, R. L. 1998. Contributions of blastocyst micromanipulation to the study of mammalian development. Bioessays 20: 168-180.

Gerard, M., Zakany, J., and Duboule, D. 1997. Interspecies exchange of a Hoxd enhancer in vivo induces premature transcription and anterior shift of the sacrum. Dev. Biol. 190: 32-40.

Gertsenstein, M., Lobe, C., and Nagy, A. 2002. ES cellmediated conditional transgenesis. Methods Mol. Biol. 185: 285-307.

Gilthorpe, J. D., and Rigby, P. W. 1999. Reporter genes for the study of transcriptional regulation in transgenic mouse embryos. Methods Mol. Biol. 97: 159-182.

Gingrich, J. R., and Roder, J. 1998. Inducible gene expression in the nervous system of transgenic mice. Annu Rev. Neurosci. 21: 377-405.

Giraldo, P., and Montoliu, L. 2001. Size matters: use of YACs, BACs and PACs in transgenic animals. Transgenic Res. 10: 83-103.

Golovan, S. P., Meidinger, R. G., Ajakaiye, A., Cottrill, M., Wiederkehr, M. Z., Barney, D. J., Plante, C., Pollard, J. W., Fan, M. Z., Hayes, M. A., Laursen, J., Hjorth, J. P., Hacker, R. R., Phillips, J. P., and Forsberg, C. W. 2001. Pigs expressing salivary phytase produce lowphosphorus manure. Nat. Biotechnol. 19: 741-745.

Gordon, J. W. 1993. Production of transgenic mice. Methods Enzy. Mol. 225: 747-771.

Gordon, J. W., and Ruddle, F. H. 1981. Integration and stable germ line transmission of genes injected into mouse pronuclei. Science 214: 1244-1246.

Gordon, J. W., Scangos, G. A., Plotkin, D. J., Barbosa, J. A., and Ruddle, F. H. 1980. Genetic transformation of mouse embryos by microinjection of purified DNA. Proc. Natl. Acad. Sci. USA. 77: 7380-7384.

Gossen, M., and Bujard, H. 1992. Tight control of gene expression in mammalian cells by tetracycline-responsive promoters. Proc. Natl. Acad. Sci. USA. 89: 5547-5551.

Gossen, M., Freundlieb, S., Bender, G., Muller, G., Hillen, W., and Bujard, H. 1995. Transcriptional activation by tetracyclines in mammalian cells. Science 268: 17661769.

Gossler, A., Joyner, A. L., Rossant, J., and Skarnes, W. C. 1989. Mouse embryonic stem cells and reporter constructs to detect developmentally regulated genes. Science 244: 463-465.

Graessmann, A., Graessmann, M., Topp, W. C., and Botchan, M. 1979. Retransformation of a simian virus 40 revertant cell line, which is resistant to viral and DNA infections, by microinjection of viral DNA. J. Virol. 32: 989994.

Graham, F. L., and van der Eb, A. J. 1973. Transformation of rat cells by DNA of human adenovirus 5 . Virology 54 : 536-539.

Greer, J. M., Puetz, J., Thomas, K. R., and Capecchi, M. R. 2000. Maintenance of functional equivalence during paralogous Hox gene evolution. Nature 403: 661-665.

Grosveld, F., van Assendelft, G. B., Greaves, D. R., and Kollias, G. 1987. Position-independent, high-level expression of the human beta-globin gene in transgenic mice. Cell 51: 975-985.

Gu, H., Marth, J. D., Orban, P. C., Mossmann, H., and Rajewsky, K. 1994. Deletion of a DNA polymerase beta gene segment in $\mathrm{T}$ cells using cell type-specific gene targeting. Science 265: 103-106.

Gussoni, E., Soneoka, Y., Strickland, C. D., Buzney, E. A., Khan, M. K., Flint, A. F., Kunkel, L. M., and Mulligan, R. C. 1999. Dystrophin expression in the $\mathrm{mdx}$ mouse restored by stem cell transplantation. Nature 401: 390394.

Hadchouel, J., Tajbakhsh, S., Primig, M., Chang, T. H., Daubas, P., Rocancourt, D., and Buckingham, M. 2000. Modular long-range regulation of Myf5 reveals unexpected heterogeneity between skeletal muscles in the mouse embryo. Development 127: 4455-4467.

Hamilton, B. A., and Frankel, W. N. 2001. Of mice and genome sequence. Cell 107: 13-16.

Hammer, R. E. 1998. Egg culture: the foundation. Int. J. Dev. Biol. 42: 833-839.

Hammer, R. E., Pursel, V. G., Rexroad, C. E., Jr., Wall, R. J., Bolt, D. J., Ebert, K. M., Palmiter, R. D., and Brinster, R. L. 1985. Production of transgenic rabbits, sheep and pigs by microinjection. Nature 315: 680-683.

Hanks, M., Wurst, W., Anson-Cartwright, L., Auerbach, A. B., and Joyner, A. L. 1995. Rescue of the En-1 mutant phenotype by replacement of En-1 with En-2. Science 269: 679-682.

Hanks, M. C., Loomis, C. A., Harris, E., Tong, C. X., AnsonCartwright, L., Auerbach, A., and Joyner, A. 1998. Drosophila engrailed can substitute for mouse Engrailed1 function in mid-hindbrain, but not limb development. 
Development 125: 4521-4530.

Hardison, R. C. 2000. Conserved noncoding sequences are reliable guides to regulatory elements. Trends Genet. 16: 369-372.

Heintz, N. 2001. BAC to the future: the use of bac transgenic mice for neuroscience research. Nat. Rev. Neurosci. 2: 861-870.

Herskowitz, I. 1987. Functional inactivation of genes by dominant negative mutations. Nature 329: 219-222.

Hew, C., Fletcher, GLand Davies, PL 1995. Transgenic salmon: Tailoring the genome for food production. J. Fish. Biol. SupplA 47: 1-9.

Hogan, B. B., R., Constantini, F., and Lacey, E. (1994). Manipulating the Mouse Embryo: A Laboratory Manual. Cold Spring Harbor, NY, CSHL Press.

Hoppe, U. C., Marban, E., and Johns, D. C. 2000. Adenovirus-mediated inducible gene expression in vivo by a hybrid ecdysone receptor. Mol. Ther 1: 159-164.

Horan, G. S., Ramirez-Solis, R., Featherstone, M. S., Wolgemuth, D. J., Bradley, A., and Behringer, R. R. 1995. Compound mutants for the paralogous Hoxa-4, Hoxb-4, and Hoxd-4 genes show more complete homeotic transformations and a dose-dependent increase in the number of vertebrae transformed. Genes Dev. 9: 16671677.

Hudson, T. J., Church, D. M., Greenaway, S., Nguyen, H., Cook, A., Steen, R. G., Van Etten, W. J., Castle, A. B., Strivens, M. A., Trickett, P., Heuston, C., Davison, C., Southwell, A., Hardisty, R., Varela-Carver, A., Haynes, A. R., Rodriguez-Tome, P., Doi, H., Ko, M. S., Pontius, J., Schriml, L., Wagner, L., Maglott, D., Brown, S. D., Lander, E. S., Schuler, G., and Denny, P. 2001. A radiation hybrid map of mouse genes. Nat. Genet. 29: 201-205.

Humpherys, D., Eggan, K., Akutsu, H., Hochedlinger, K., Rideout, W. M., 3rd, Biniszkiewicz, D., Yanagimachi, R., and Jaenisch, R. 2001. Epigenetic instability in ES cells and cloned mice. Science 293: 95-97.

Ikawa, M., Yamada, S., Nakanishi, T., and Okabe, M. 1998. 'Green mice' and their potential usage in biological research. FEBS Lett 430: 83-87.

Illmensee, K., and Hoppe, P. C. 1981. Nuclear transplantation in Mus musculus: developmental potential of nuclei from preimplantation embryos. Cell 23: 9-18.

loannou, P. A., Amemiya, C. T., Garnes, J., Kroisel, P. M., Shizuya, H., Chen, C., Batzer, M. A., and de Jong, P. J. 1994. A new bacteriophage P1-derived vector for the propagation of large human DNA fragments. Nat. Genet. 6: 84-89.

Jaenisch, R. 1976. Germ line integration and Mendelian transmission of the exogenous Moloney leukemia virus. Proc. Natl. Acad. Sci. USA. 73: 1260-1264.

Jahner, D., Haase, K., Mulligan, R., and Jaenisch, R. 1985. Insertion of the bacterial gpt gene into the germ line of mice by retroviral infection. Proc. Natl. Acad. Sci. USA. 82: 6927-6931.

Jakobovits, A., Moore, A. L., Green, L. L., Vergara, G. J., Maynard-Currie, C. E., Austin, H. A., and Klapholz, S. 1993. Germ-line transmission and expression of a humanderived yeast artificial chromosome. Nature 362: 255258.

Jasin, M., Moynahan, M. E., and Richardson, C. 1996.
Targeted transgenesis [comment]. Proc. Natl. Acad. Sci. USA. 93: 8804-8808.

Jessen, J. R., Meng, A., McFarlane, R. J., Paw, B. H., Zon, L. I., Smith, G. R., and Lin, S. 1998. Modification of bacterial artificial chromosomes through chi-stimulated homologous recombination and its application in zebrafish transgenesis. Proc. Natl. Acad. Sci. USA. 95: 5121-5126. John, R. M., Aparicio, S. A., Ainscough, J. F., Arney, K. L., Khosla, S., Hawker, K., Hilton, K. J., Barton, S. C., and Surani, M. A. 2001. Imprinted expression of neuronatin from modified BAC transgenes reveals regulation by distinct and distant enhancers. Dev. Biol. 236: 387-399. Justice, M. J. 2000. Capitalizing on large-scale mouse mutagenesis screens. Nat. Rev. Genet. 1: 109-115.

Kawai, J., Shinagawa, A., Shibata, K., Yoshino, M., Itoh, M., Ishii, Y., Arakawa, T., Hara, A., Fukunishi, Y., Konno, H., Adachi, J., Fukuda, S., Aizawa, K., Izawa, M., Nishi, K., Kiyosawa, H., Kondo, S., Yamanaka, I., Saito, T., Okazaki, Y., Gojobori, T., Bono, H., Kasukawa, T., Saito, R., Kadota, K., Matsuda, H. A., Ashburner, M., Batalov, S., Casavant, T., Fleischmann, W., Gaasterland, T., Gissi, C., King, B., Kochiwa, H., Kuehl, P., Lewis, S., Matsuo, Y., Nikaido, I., Pesole, G., Quackenbush, J., Schriml, L. M., Staubli, F., Suzuki, R., Tomita, M., Wagner, L., Washio, T., Sakai, K., Okido, T., Furuno, M., Aono, H., Baldarelli, R., Barsh, G., Blake, J., Boffelli, D., Bojunga, N., Carninci, P., de Bonaldo, M. F., Brownstein, M. J., Bult, C., Fletcher, C., Fujita, M., Gariboldi, M., Gustincich, S., Hill, D., Hofmann, M., Hume, D. A., Kamiya, M., Lee, N. H., Lyons, P., Marchionni, L., Mashima, J., Mazzarelli, J., Mombaerts, P., Nordone, P., Ring, B., Ringwald, M., Rodriguez, I., Sakamoto, N., Sasaki, H., Sato, K., Schonbach, C., Seya, T., Shibata, Y., Storch, K. F., Suzuki, H., Toyo-oka, K., Wang, K. H., Weitz, C., Whittaker, C., Wilming, L., Wynshaw-Boris, A., Yoshida, K., Hasegawa, Y., Kawaji, H., Kohtsuki, S., and Hayashizaki, Y. 2001. Functional annotation of a full-length mouse cDNA collection. Nature 409: 685-690.

Kim, C. B., Amemiya, C., Bailey, W., Kawasaki, K., Mezey, J., Miller, W., Minoshima, S., Shimizu, N., Wagner, G., and Ruddle, F. 2000. Hox cluster genomics in the horn shark, Heterodontus francisci. Proc. Natl. Acad. Sci. USA. 97: 1655-1660.

Kitajima, K., and Takeuchi, T. 1998. Mouse gene trap approach: identification of novel genes and characterization of their biological functions. Biochem Cell Biol. 76: 1029-1037.

Klug, M. G., Soonpaa, M. H., Koh, G. Y., and Field, L. J. 1996. Genetically selected cardiomyocytes from differentiating embronic stem cells form stable intracardiac grafts. J. Clin Invest 98: 216-224.

Kmita, M., Kondo, T., and Duboule, D. 2000. Targeted inversion of a polar silencer within the HoxD complex reallocates domains of enhancer sharing. Nat. Genet. 26: 451-454.

Koller, B. H., Hagemann, L. J., Doetschman, T., Hagaman, J. R., Huang, S., Williams, P. J., First, N. L., Maeda, N., and Smithies, O. 1989. Germ-line transmission of a planned alteration made in a hypoxanthine phosphoribosyltransferase gene by homologous recombination in embryonic stem cells. Proc. Natl. Acad. 
Sci. USA. 86: 8927-8931.

Kondo, T., and Duboule, D. 1999. Breaking colinearity in the mouse HoxD complex. Cell 97: 407-417.

Korn, R., Schoor, M., Neuhaus, H., Henseling, U., Soininen, R., Zachgo, J., and Gossler, A. 1992. Enhancer trap integrations in mouse embryonic stem cells give rise to staining patterns in chimaeric embryos with a high frequency and detect endogenous genes. Mech Dev. 39: 95-109.

Kothary, R., Clapoff, S., Brown, A., Campbell, R., Peterson, A., and Rossant, J. 1988. A transgene containing lacZ inserted into the dystonia locus is expressed in neural tube. Nature 335: 435-437.

Kothary, R., Clapoff, S., Darling, S., Perry, M. D., Moran, L. A., and Rossant, J. 1989. Inducible expression of an hsp68-lacZhybrid gene in transgenic mice. Development 105: 707-714.

Kowalczykowski, S. C., Dixon, D. A., Eggleston, A. K., Lauder, S. D., and Rehrauer, W. M. 1994. Biochemistry of homologous recombination in Escherichia coli. Microbiol. Rev. 58: 401-465.

Krempen, K., Grotkopp, D., Hall, K., Bache, A., Gillan, A., Rippe, R.A., Brenner, D.A., Breindl, M. 1999. Far upstream regulatory elements enhance positionindependent and uterus-specific expression of the murine alpha1(I) collagen promoter in transgenic mice. Gene Expr. 8: 151-63.

Kroll, K. L., and Amaya, E. 1996. Transgenic Xenopus embryos from sperm nuclear transplantations reveal FGF signaling requirements during gastrulation. Development 122: 3173-3183.

Kucherlapati, R. S., Eves, E. M., Song, K. Y., Morse, B. S., and Smithies, O. 1984. Homologous recombination between plasmids in mammalian cells can be enhanced by treatment of input DNA. Proc. Natl. Acad. Sci. USA. 81: 3153-3157.

Kuehn, M. R., Bradley, A., Robertson, E. J., and Evans, M. J. 1987. A potential animal model for Lesch-Nyhan syndrome through introduction of HPRT mutations into mice. Nature 326: 295-298.

Kumar, A., and Snyder, M. 2001. Emerging technologies in yeast genomics. Nat. Rev. Genet. 2: 302-312.

L'Huillier, P. J., Soulier, S., Stinnakre, M. G., Lepourry, L., Davis, S. R., Mercier, J. C., and Vilotte, J. L. 1996. Efficient and specific ribozyme-mediated reduction of bovine alpha-lactalbumin expression in double transgenic mice. Proc. Natl. Acad. Sci. USA. 93: 6698-6703.

Lai, L., Kolber-Simonds, D., Park, K. W., Cheong, H. T., Greenstein, J. L., Im, G. S., Samuel, M., Bonk, A., Rieke, A., Day, B. N., Murphy, C. N., Carter, D. B., Hawley, R. J., and Prather, R. S. 2002. Production of \{alpha\}-1,3galactosyltransferase knockout pigs by nuclear transfer cloning. Science 3: 3.

Lakso, M., Sauer, B., Mosinger, B., Jr., Lee, E. J., Manning, R. W., Yu, S. H., Mulder, K. L., and Westphal, H. 1992. Targeted oncogene activation by site-specific recombination in transgenic mice. Proc. Natl. Acad. Sci. USA. 89: 6232-6236.

Lamb, B. T., and Gearhart, J. D. 1995. YAC transgenics and the study of genetics and human disease. Curr. Opin. Genet. Dev. 5: 342-348.
Lavitrano, M., Camaioni, A., Fazio, V. M., Dolci, S., Farace, M. G., and Spadafora, C. 1989. Sperm cells as vectors for introducing foreign DNA into eggs: genetic transformation of mice [see comments]. Cell 57:717-723.

Lee, E. C., Yu, D., Martinez de Velasco, J., Tessarollo, L., Swing, D. A., Court, D. L., Jenkins, N. A., and Copeland, N. G. 2001. A highly efficient Escherichia coli-based chromosome engineering system adapted for recombinogenic targeting and subcloning of BAC DNA. Genomics 73: 56-65.

Lee, J. T., and Jaenisch, R. 1997. Long-range cis effects of ectopic $\mathrm{X}$-inactivation centres on a mouse autosome. Nature 386: 275-279.

Lewandoski, M. 2001. Conditional control of gene expression in the mouse. Nat. Rev. Genet. 2: 743-755.

Li, X., Wang, W., and Lufkin, T. 1997. Dicistronic LacZ and alkaline phosphatase reporter constructs permit simultaneous histological analysis of expression from multiple transgenes. Biotechniques 23: 874-878, 880, 882.

Lindsay, E. A., Botta, A., Jurecic, V., Carattini-Rivera, S., Cheah, Y. C., Rosenblatt, H. M., Bradley, A., and Baldini, A. 1999. Congenital heart disease in mice deficient for the DiGeorge syndrome region. Nature 401: 379-383.

Lindsay, E. A., Vitelli, F., Su, H., Morishima, M., Huynh, T., Pramparo, T., Jurecic, V., Ogunrinu, G., Sutherland, H. F., Scambler, P. J., Bradley, A., and Baldini, A. 2001. Tbx1 haploinsufficieny in the DiGeorge syndrome region causes aortic arch defects in mice. Nature 410: 97-101.

Liu, P., Zhang, H., McLellan, A., Vogel, H., and Bradley, A. 1998. Embryonic lethality and tumorigenesis caused by segmental aneuploidy on mouse chromosome 11. Genetics 150: 1155-1168.

Loi, P., Ptak, G., Barboni, B., Fulka, J., Jr., Cappai, P., and Clinton, M. 2001. Genetic rescue of an endangered mammal by cross-species nuclear transfer using postmortem somatic cells. Nat. Biotechnol. 19: 962-964.

Lovell-Badge, R. 2001. The future for stem cell research. Nature 414: 88-91.

Luciw, P. A., Bishop, J. M., Varmus, H. E., and Capecchi, M. R. 1983. Location and function of retroviral and SV40 sequences that enhance biochemical transformation after microinjection of DNA. Cell 33: 705-716.

Luyckx, V. A., Leclercq, B., Dowland, L. K., and Yu, A. S. 1999. Diet-dependent hypercalciuria in transgenic mice with reduced CLC5 chloride channel expression. Proc. Natl. Acad. Sci. USA. 96: 12174-12179.

MacDonald, R. J., and Swift, G. H. 1998. Analysis of transcriptional regulatory regions in vivo. Int. J. Dev. Biol. 42: 983-994.

Mansour, S. L., Thomas, K. R., and Capecchi, M. R. 1988. Disruption of the proto-oncogene int-2 in mouse embryoderived stem cells: a general strategy for targeting mutations to non-selectable genes. Nature 336: 348-352. Marshall, H., Studer, M., Popperl, H., Aparicio, S., Kuroiwa, A., Brenner, S., and Krumlauf, R. 1994. A conserved retinoic acid response element required for early expression of the homeobox gene Hoxb-1. Nature 370: 567-571.

McCreath, K. J., Howcroft, J., Campbell, K. H., Colman, A., Schnieke, A. E., and Kind, A. J. 2000. Production of 
gene-targeted sheep by nuclear transfer from cultured somatic cells. Nature 405: 1066-1069.

McDevitt, M. A., Shivdasani, R. A., Fujiwara, Y., Yang, H., and Orkin, S. H. 1997. A "knockdown" mutation created by cis-element gene targeting reveals the dependence of erythroid cell maturation on the level of transcription factor GATA-1. Proc. Natl. Acad. Sci. USA. 94: 6781-6785. McGrath, J., and Solter, D. 1984. Completion of mouse embryogenesis requires both the maternal and paternal genomes. Cell 37: 179-183.

McLaren, A. 2000. Cloning: pathways to a pluripotent future. Science 288: 1775-1780.

Merscher, S., Funke, B., Epstein, J. A., Heyer, J., Puech, A., Lu, M. M., Xavier, R. J., Demay, M. B., Russell, R. G., Factor, S., Tokooya, K., Jore, B. S., Lopez, M., Pandita, R. K., Lia, M., Carrion, D., Xu, H., Schorle, H., Kobler, J. B., Scambler, P., Wynshaw-Boris, A., Skoultchi, A. I., Morrow, B. E., and Kucherlapati, R. 2001. TBX1 is responsible for cardiovascular defects in velo-cardiofacial/DiGeorge syndrome. Cell 104: 619-629.

Mezey, E., Chandross, K. J., Harta, G., Maki, R. A., and McKercher, S. R. 2000. Turning blood into brain: cells bearing neuronal antigens generated in vivo from bone marrow. Science 290: 1779-1782.

Mills, A. A. 2001. Changing colors in mice: an inducible system that delivers. Genes Dev. 15: 1461-1467.

Mills, A. A., and Bradley, A. 2001. From mouse to man: generating megabase chromosome rearrangements. Trends Genet. 17: 331-339.

Mintz, B., and Illmensee, K. 1975. Normal genetically mosaic mice produced from malignant teratocarcinoma cells. Proc. Natl. Acad. Sci. USA. 72: 3585-3589.

Mohn, A. R., Gainetdinov, R. R., Caron, M. G., and Koller, B. H. 1999. Mice with reduced NMDA receptor expression display behaviors related to schizophrenia. Cell 98: 427436.

Morrison, A., Chaudhuri, C., Ariza-McNaughton, L., Muchamore, I., Kuroiwa, A., and Krumlauf, R. 1995. Comparative analysis of chicken Hoxb-4 regulation in transgenic mice. Mech. Dev. 53: 47-59.

Muir, W. M., and Howard, R. D. 1999. Possible ecological risks of transgenic organism release when transgenes affect mating success: sexual selection and the Trojan gene hypothesis. Proc. Natl. Acad. Sci. USA. 96: 1385313856.

Muller, U. 1999. Ten years of gene targeting: targeted mouse mutants, from vector design to phenotype analysis. Mech. Dev. 82: 3-21.

Murray, J. D. 1999. Genetic modification of animals in the next century. Theriogenology 51: 149-159.

Muyrers, J., Zhang, YM, Stewart, AF 2001. Recombinogenic engineering - new options for cloning and manipulating DNA. Trends.Biochem.Sci. 26: 325-351.

Myers, R. S., and Stahl, F. W. 1994. Chi and the RecBC D enzyme of Escherichia coli. Annu Rev. Genet. 28: 49-70.

Nadeau, J. H., Singer, J. B., Matin, A., and Lander, E. S. 2000. Analysing complex genetic traits with chromosome substitution strains. Nat. Genet. 24: 221-225.

Nagy, A. 2000. Cre recombinase: the universal reagent for genome tailoring. Genesis 26: 99-109.

Nagy, A., and Mar, L. 2001. Creation and use of a Cre recombinase transgenic database. Methods Mol. Biol. 158: 95-106.

Niemann, H., and Kues, W. A. 2000. Transgenic livestock: premises and promises. Anim. Reprod. Sci. 60-61: 277293.

No, D., Yao, T. P., and Evans, R. M. 1996. Ecdysoneinducible gene expression in mammalian cells and transgenic mice. Proc. Natl. Acad. Sci. USA. 93: 33463351.

Nolan, P. M., Peters, J., Strivens, M., Rogers, D., Hagan, J., Spurr, N., Gray, I. C., Vizor, L., Brooker, D., Whitehill, E., Washbourne, R., Hough, T., Greenaway, S., Hewitt, M., Liu, X., McCormack, S., Pickford, K., Selley, R., Wells, C., Tymowska-Lalanne, Z., Roby, P., Glenister, P., Thornton, C., Thaung, C., Stevenson, J. A., Arkell, R., Mburu, P., Hardisty, R., Kiernan, A., Erven, A., Steel, K. P., Voegeling, S., Guenet, J. L., Nickols, C., Sadri, R., Nasse, M., Isaacs, A., Davies, K., Browne, M., Fisher, E. M., Martin, J., Rastan, S., Brown, S. D., and Hunter, J. 2000. A systematic, genome-wide, phenotype-driven mutagenesis programme for gene function studies in the mouse. Nat. Genet. 25: 440-443.

O'Gorman, S., Fox, D. T., and Wahl, G. M. 1991. Recombinase-mediated gene activation and site-specific integration in mammalian cells. Science 251: 1351-1355.

Oliner, J. D., Kinzler, K. W., and Vogelstein, B. 1993. In vivo cloning of $\mathrm{PCR}$ products in $E$. coli. Nucleic Acids Res. 21: 5192-5197.

Onishi, A., Iwamoto, M., Akita, T., Mikawa, S., Takeda, K., Awata, T., Hanada, H., and Perry, A. C. 2000. Pig cloning by microinjection of fetal fibroblast nuclei. Science 289 : 1188-1190.

Ornitz, D. M., Moreadith, R. W., and Leder, P. 1991. Binary system for regulating transgene expression in mice: targeting int-2 gene expression with yeast GAL4/UAS control elements. Proc. Natl. Acad. Sci. USA. 88: 698702.

Palmiter, R. D. 1998. Transgenic mice-the early days. Int. J. Dev. Biol. 42: 847-854.

Palmiter, R. D., Brinster, R. L., Hammer, R. E., Trumbauer, M. E., Rosenfeld, M. G., Birnberg, N. C., and Evans, R. M. 1982. Dramatic growth of mice that develop from eggs microinjected with metallothionein-growth hormone fusion genes. Nature 300: 611-615.

Papaioannou, V. E., McBurney, M. W., Gardner, R. L., and Evans, M. J. 1975. Fate of teratocarcinoma cells injected into early mouse embryos. Nature 258: 70-73.

Perlmutter, R. M., and Alberola-lla, J. 1996. The use of dominant-negative mutations to elucidate signal transduction pathways in lymphocytes. Curr. Opin. Immunol 8: 285-290.

Perry, A. C., Wakayama, T., Kishikawa, H., Kasai, T., Okabe, M., Toyoda, Y., and Yanagimachi, R. 1999. Mammalian transgenesis by intracytoplasmic sperm injection [see comments]. Science 284: 1180-1183.

Peterson, K. R., Clegg, C. H., Li, Q., and Stamatoyannopoulos, G. 1997. Production of transgenic mice with yeast artificial chromosomes. Trends Genet. 13: 61-66.

Polejaeva, I. A., Chen, S. H., Vaught, T. D., Page, R. L., Mullins, J., Ball, S., Dai, Y., Boone, J., Walker, S., Ayares, 
D. L., Colman, A., and Campbell, K. H. 2000. Cloned pigs produced by nuclear transfer from adult somatic cells. Nature 407: 86-90.

Prather, R. S., Barnes, F. L., Sims, M. M., Robl, J. M., Eyestone, W. H., and First, N. L. 1987. Nuclear transplantation in the bovine embryo: assessment of donor nuclei and recipient oocyte. Biol. Reprod 37: 859866.

Pursel, V. G., Bolt, D. J., Miller, K. F., Pinkert, C. A., Hammer, R. E., Palmiter, R. D., and Brinster, R. L. 1990. Expression and performance in transgenic pigs. J. Reprod. Fertil. Suppl. 40: 235-245.

Pursel, V. G., Pinkert, C. A., Miller, K. F., Bolt, D. J., Campbell, R. G., Palmiter, R. D., Brinster, R. L., and Hammer, R. E. 1989. Genetic engineering of livestock. Science 244: 1281-1288.

Ramirez-Solis, R., Liu, P., and Bradley, A. 1995. Chromosome engineering in mice. Nature 378: 720-724.

Rampon, C., Tang, Y. P., Goodhouse, J., Shimizu, E., Kyin, M., and Tsien, J. Z. 2000. Enrichment induces structural changes and recovery from nonspatial memory deficits in CA1 NMDAR1-knockout mice. Nat. Neurosci. 3: 238244.

Reik, W., Constancia, M., Dean, W., Davies, K., Bowden, L., Murrell, A., Feil, R., Walter, J., and Kelsey, G. 2000. lgf2 imprinting in development and disease. Int. J. Dev. Biol. 44: 145-150.

Reik, W., Dean, W., and Walter, J. 2001. Epigenetic reprogramming in mammalian development. Science 293: 1089-1093.

Reizis, B., and Leder, P. 2001. The upstream enhancer is necessary and sufficient for the expression of the pre-T cell receptor alpha gene in immature T lymphocytes. J. Exp. Med. 194: 979-990.

Reya, T., Morrison, S. J., Clarke, M. F., and Weissman, I. L. 2001. Stem cells, cancer, and cancer stem cells. Nature 414: 105-111.

Rideout, W. M., 3rd, Wakayama, T., Wutz, A., Eggan, K., Jackson-Grusby, L., Dausman, J., Yanagimachi, R., and Jaenisch, R. 2000. Generation of mice from wild-type and targeted ES cells by nuclear cloning. Nat. Genet. 24: 109110.

Ruddle, F. H. 1981. A new era in mammalian gene mapping: somatic cell genetics and recombinant DNA methodologies. Nature 294: 115-120.

Rudolph, N. S. 1999. Biopharmaceutical production in transgenic livestock. Trends Biotechnol. 17: 367-374.

Saez, E., Nelson, M. C., Eshelman, B., Banayo, E., Koder, A., Cho, G. J., and Evans, R. M. 2000. Identification of ligands and coligands for the ecdysone-regulated gene switch. Proc. Natl. Acad. Sci. USA. 97: 14512-14517.

Sauer, B. 1998. Inducible gene targeting in mice using the Cre/lox system. Methods 14: 381-392.

Sauer, B., and Henderson, N. 1988. Site-specific DNA recombination in mammalian cells by the Cre recombinase of bacteriophage P1. Proc. Natl. Acad. Sci. USA. 85: 5166-5170.

Scangos, G., and Ruddle, F. H. 1981. Mechanisms and applications of DNA-mediated gene transfer in mammalian cells - a review. Gene 14: 1-10.

Schaft, J., Ashery-Padan, R., van der Hoeven, F., Gruss,
P., and Stewart, A. F. 2001. Efficient FLP recombination in mouse ES cells and oocytes. Genesis 31: 6-10.

Schedl, A., Montoliu, L., Kelsey, G., and Schutz, G. 1993. A yeast artificial chromosome covering the tyrosinase gene confers copy number-dependent expression in transgenic mice. Nature 362: 258-261.

Schnieke, A. E., Kind, A. J., Ritchie, W. A., Mycock, K., Scott, A. R., Ritchie, M., Wilmut, I., Colman, A., and Campbell, K. H. 1997. Human factor IX transgenic sheep produced by transfer of nuclei from transfected fetal fibroblasts. Science 278: 2130-2133.

Schwartzberg, P. L., Goff, S. P., and Robertson, E. J. 1989. Germ-line transmission of a c-abl mutation produced by targeted gene disruption in ES cells. Science 246: 799803.

Schweifer, N., Valk, P. J., Delwel, R., Cox, R., Francis, F., Meier-Ewert, S., Lehrach, H., and Barlow, D. P. 1997. Characterization of the C3 YAC contig from proximal mouse chromosome 17 and analysis of allelic expression of genes flanking the imprinted Igf2r gene. Genomics 43: 285-297.

Sham, M. H., Vesque, C., Nonchev, S., Marshall, H., Frain, M., Gupta, R. D., Whiting, J., Wilkinson, D., Charnay, P., and Krumlauf, R. 1993. The zinc finger gene Krox20 regulates HoxB2 (Hox2.8) during hindbrain segmentation. Cell 72: 183-196.

Shashikant, C., Ruddle, FH (2001). Transgenic mouse models. Lung Biology in Health and Disease. C. Lenfant. New York, Marcel Dekker. 152: 35-58.

Shashikant, C. S., Carr, J. L., Bhargava, J., Bentley, K. L., and Ruddle, F. H. 1998a. Recombinogenic targeting: a new approach to genomic analysis - a review. Gene 223: 9-20.

Shashikant, C. S., Kim, C. B., Borbely, M. A., Wang, W. C., and Ruddle, F. H. 1998b. Comparative studies on mammalian Hoxc8 early enhancer sequence reveal a baleen whale-specific deletion of a cis-acting element. Proc. Natl. Acad. Sci. USA. 95: 15446-15451.

Shashikant, C. S., and Ruddle, F. H. 1996. Combinations of closely situated cis-acting elements determine tissuespecific patterns and anterior extent of early Hoxc8 expression. Proc. Natl. Acad. Sci. USA. 93: 12364-12369.

Shewchuk, B.M., Asa, S.L., Cooke, N.E., and Liebhaber, S.A. 1999. Pit-1 binding sites at the somatotrope-specific DNase I hypersensitive sites I, II of the human growth hormone locus control region are essential for in vivo hGH-N gene activation. J. Biol. Chem. 274: 3572535733.

Shizuya, H., Birren, B., Kim, U. J., Mancino, V., Slepak, T., Tachiiri, Y., and Simon, M. 1992. Cloning and stable maintenance of 300-kilobase-pair fragments of human DNA in Escherichia coli using an F-factor-based vector. Proc. Natl. Acad. Sci. USA. 89: 8794-8797.

Skarnes, W. C., Moss, J. E., Hurtley, S. M., and Beddington, R. S. 1995. Capturing genes encoding membrane and secreted proteins important for mouse development. Proc. Natl. Acad. Sci. USA. 92: 6592-6596.

Smith, A. G., Heath, J. K., Donaldson, D. D., Wong, G. G., Moreau, J., Stahl, M., and Rogers, D. 1988. Inhibition of pluripotential embryonic stem cell differentiation by purified polypeptides. Nature 336: 688-690. 
Smith, A. G., and Hooper, M. L. 1987. Buffalo rat liver cells produce a diffusible activity which inhibits the differentiation of murine embryonal carcinoma and embryonic stem cells. Dev. Biol. 121: 1-9.

Smith, D. J., Stevens, M. E., Sudanagunta, S. P., Bronson, R. T., Makhinson, M., Watabe, A. M., O'Dell, T. J., Fung, J., Weier, H. U., Cheng, J. F., and Rubin, E. M. 1997. Functional screening of $2 \mathrm{Mb}$ of human chromosome 21 q22.2 in transgenic mice implicates minibrain in learning defects associated with Down syndrome [see comments]. Nat. Genet. 16: 28-36.

Smithies, O. 2001. Forty years with homologous recombination. Nat. Med. 7: 1083-1086.

Smithies, O., Gregg, R. G., Boggs, S. S., Koralewski, M. A., and Kucherlapati, R. S. 1985. Insertion of DNA sequences into the human chromosomal beta-globin locus by homologous recombination. Nature 317: 230234.

Snouwaert, J. N., Brigman, K. K., Latour, A. M., Malouf, N. N., Boucher, R. C., Smithies, O., and Koller, B. H. 1992. An animal model for cystic fibrosis made by gene targeting. Science 257: 1083-1088.

Solaiman, F., Zink, M. A., Xu, G., Grunkemeyer, J., Cosgrove, D., Saenz, J., and Hodgson, C. P. 2000. Modular retro-vectors for transgenic and therapeutic use. Mol. Reprod Dev. 56: 309-315.

Solter, D. 1998. Imprinting. Int. J. Dev. Biol. 42: 951-954.

Solter, D. 2000. Mammalian cloning: advances and limitations. Nat. Rev. Genet. 1: 199-207.

Spergel, D. J., Kruth, U., Shimshek, D. R., Sprengel, R., and Seeburg, P. H. 2001. Using reporter genes to label selected neuronal populations in transgenic mice for gene promoter, anatomical, and physiological studies. Prog. Neuro. Biol. 63: 673-686.

Spitz, F., Gonzalez, F., Peichel, C., Vogt, T. F., Duboule, D., and Zakany, J. 2001. Large scale transgenic and cluster deletion analysis of the HoxD complex separate an ancestral regulatory module from evolutionary innovations. Genes Dev. 15: 2209-2214.

Spradling, A., Drummond-Barbosa, D., and Kai, T. 2001. Stem cells find their niche. Nature 414: 98-104.

Stanford, W. L., Cohn, J. B., and Cordes, S. P. 2001. Genetrap mutagenesis: past, present and beyond. Nat. Rev. Genet. 2: 756-768.

Sternberg, N. L. 1992. Cloning high molecular weight DNA fragments by the bacteriophage P1 system. Trends Genet. 8: 11-16.

Stevens, L. C. 1967. The biology of teratomas. Adv. Morphog. 6: 1-31.

Su, H. Y., Jay, N. P., Gourley, T. S., Kay, G. W., and Damak, S. 1998. Wool production in transgenic sheep: results from first-generation adults and second-generation lambs. Anim. Biotechnol. 9: 135-147.

Sumiyama, K., Kim, C. B., and Ruddle, F. H. 2001. An efficient cis-element discovery method using multiple sequence comparisons based on evolutionary relationships. Genomics 71: 260-262.

Sun, F. L., and Elgin, S. C. 1999. Putting boundaries on silence. Cell 99: 459-462.

Surani, M. A. 2001. Reprogramming of genome function through epigenetic inheritance. Nature 414: 122-128.
Symula, D. J., Frazer, K. A., Ueda, Y., Denefle, P., Stevens, M. E., Wang, Z. E., Locksley, R., and Rubin, E. M. 1999. Functional screening of an asthma QTL in YAC transgenic mice. Nat. Genet. 23: 241-244.

Szostak, J. W., Orr-Weaver, T. L., Rothstein, R. J., and Stahl, F. W. 1983. The double-strand-break repair model for recombination. Cell 33: 25-35.

Szybalska, E. A., Szybalska, W. 1962. Genetics of human cell lines IV. Proc. Natl. Acad. Sci. USA. 48: 2026-2034. Talbot, D., Descombes, P., and Schibler, U. 1994. The 5' flanking region of the rat LAP (C/EBP beta) gene can direct high-level, position-independent, copy numberdependent expression in multiple tissues in transgenic mice. Nucleic Acids Res. 22: 756-766.

Tanimoto, K., Liu, Q., Bungert, J., and Engel, J. D. 1999. Effects of altered gene order or orientation of the locus control region on human beta-globin gene expression in mice. Nature 398: 344-348.

Temple, S. 2001. The development of neural stem cells. Nature 414: 112-117.

Thomas, M.K., Devon, O.N., Lee, J.H., Peter, A., Schlosser, D.A., Tenser, M.S., and Habener, J.F. 2001. Development of diabetes mellitus in aging transgenic mice following suppression of pancreatic homeoprotein IDX-1. J. Clin. Invest. 108: 319-29.

Thomson, J. A., Itskovitz-Eldor, J., Shapiro, S. S., Waknitz, M. A., Swiergiel, J. J., Marshall, V. S., and Jones, J. M. 1998. Embryonic stem cell lines derived from human blastocysts. Science 282: 1145-1147.

Thomson, J. A., and Odorico, J. S. 2000. Human embryonic stem cell and embryonic germ cell lines. Trends Biotechnol. 18: 53-57.

Toma, J. G., Akhavan, M., Fernandes, K. J., BarnabeHeider, F., Sadikot, A., Kaplan, D. R., and Miller, F. D. 2001. Isolation of multipotent adult stem cells from the dermis of mammalian skin. Nat. Cell Biol. 3: 778-784.

Tsai, T. F., Jiang, Y. H., Bressler, J., Armstrong, D., and Beaudet, A. L. 1999. Paternal deletion from Snrpn to Ube3a in the mouse causes hypotonia, growth retardation and partial lethality and provides evidence for a gene contributing to Prader-Willi syndrome. Hum. Mol. Genet. 8: 1357-1364.

Tybulewicz, V. L., Tremblay, M. L., LaMarca, M. E., Willemsen, R., Stubblefield, B. K., Winfield, S., Zablocka, B., Sidransky, E., Martin, B. M., Huang, S. P., and et al., 1992. Animal model of Gaucher's disease from targeted disruption of the mouse glucocerebrosidase gene. Nature 357: 407-410.

van der Putten, H., Botteri, F. M., Miller, A. D., Rosenfeld, M. G., Fan, H., Evans, R. M., and Verma, I. M. 1985. Efficient insertion of genes into the mouse germ line via retroviral vectors. Proc. Natl. Acad. Sci. USA. 82: 61486152.

Vogel, G. 2001. Endangered species. Cloned gaur a shortlived success. Science 291: 409.

von Melchner, H., DeGregori, J. V., Rayburn, H., Reddy, S., Friedel, C., and Ruley, H. E. 1992. Selective disruption of genes expressed in totipotent embryonal stem cells. Genes Dev. 6: 919-927.

von Melchner, H., and Ruley, H. E. 1989. Identification of cellular promoters by using a retrovirus promoter trap. J. 
Virol. 63: 3227-3233.

Wakayama, T., Tateno, H., Mombaerts, P., and Yanagimachi, R. 2000. Nuclear transfer into mouse zygotes. Nat. Genet. 24: 108-109.

Wang, X. J., Liefer, K. M., Tsai, S., O'Malley, B. W., and Roop, D. R. 1999. Development of gene-switch transgenic mice that inducibly express transforming growth factor beta1 in the epidermis. Proc. Natl. Acad. Sci. USA. 96: 8483-8488.

Wang, Y., DeMayo, F. J., Tsai, S. Y., and O'Malley, B. W. 1997. Ligand-inducible and liver-specific target gene expression in transgenic mice. Nat. Biotechnol. 15: 239243.

Wang, Y., and Jaenisch, R. 1997. Myogenin can substitute for Myf5 in promoting myogenesis but less efficiently. Development 124: 2507-2513.

Wang, Y., O'Malley, B. W., Jr., Tsai, S. Y., and O'Malley, B. W. 1994. A regulatory system for use in gene transfer. Proc. Natl. Acad. Sci. USA. 91: 8180-8184.

Wang, Y., Schnegelsberg, P. N., Dausman, J., and Jaenisch, R. 1996. Functional redundancy of the musclespecific transcription factors Myf5 and myogenin. Nature 379: 823-825.

Ward, K. A., and Brown, B. W. 1998. The production of transgenic domestic livestock: successes, failures, and the need for nuclear transfer. Reprod Fertil Dev. 10: 659665.

Welch, P. J., Barber, J. R., and Wong-Staal, F. 1998. Expression of ribozymes in gene transfer systems to modulate target RNA levels. Curr. Opin. Biotechnol. 9: 486-496.

Willadsen, S. M. 1986. Nuclear transplantation in sheep embryos. Nature 320: 63-65.

Williams, R. L., Hilton, D. J., Pease, S., Willson, T. A., Stewart, C. L., Gearing, D. P., Wagner, E. F., Metcalf, D., Nicola, N. A., and Gough, N. M. 1988. Myeloid leukaemia inhibitory factor maintains the developmental potential of embryonic stem cells. Nature 336: 684-687.

Willoughby, D. A., Vilalta, A., and Oshima, R. G. 2000. An Alu element from the K18 gene confers positionindependent expression in transgenic mice. J. Biol. Chem 275: 759-768.

Wilmut, I., Schnieke, A. E., McWhir, J., Kind, A. J., and Campbell, K. H. 1997. Viable offspring derived from fetal and adult mammalian cells. Nature 385: 810-813.

Wilmut, I., Young, L., and Campbell, K. H. 1998. Embryonic and somatic cell cloning. Reprod. Fertil. Dev. 10: 639643.

Yang, X. W., Model, P., and Heintz, N. 1997. Homologous recombination based modification in Escherichia coli and germline transmission in transgenic mice of a bacterial artificial chromosome [see comments]. Nat. Biotechnol. 15: 859-865.
Yang, X. W., Wynder, C., Doughty, M. L., and Heintz, N. 1999. BAC-mediated gene-dosage analysis reveals a role for Zipro1 (Ru49/Zfp38) in progenitor cell proliferation in cerebellum and skin [see comments]. Nat. Genet. 22: 327335.

Yao, T. P., Forman, B. M., Jiang, Z., Cherbas, L., Chen, J. D., McKeown, M., Cherbas, P., and Evans, R. M. 1993. Functional ecdysone receptor is the product of EcR and Ultraspiracle genes. Nature 366: 476-479.

Yu, Y., and Bradley, A. 2001. Engineering chromosomal rearrangements in mice. Nat. Rev. Genet. 2: 780-790.

Yueh, Y. G., Gardner, D. P., and Kappen, C. 1998. Evidence for regulation of cartilage differentiation by the homeobox gene Hoxc-8. Proc. Natl. Acad. Sci. USA. 95: 9956-9961.

Yuen, P. S. 1999. Dominant negative mutants of guanylyl cyclase: probes for global functions and intramolecular mechanisms. Methods 19: 532-544.

Zambrowicz, B. P., and Friedrich, G. A. 1998. Comprehensive mammalian genetics: history and future prospects of gene trapping in the mouse. Int. J. Dev. Biol. 42: $1025-1036$.

Zambrowicz, B. P., Friedrich, G. A., Buxton, E. C., Lilleberg, S. L., Person, C., and Sands, A. T. 1998. Disruption and sequence identification of 2,000 genes in mouse embryonic stem cells. Nature 392: 608-611.

Zhang, Y., Buchholz, F., Muyrers, J. P., and Stewart, A. F. 1998. A new logic for DNA engineering using recombination in Escherichia coli. Nat. Genet. 20: 123128.

Zhang, Y., Riesterer, C., Ayrall, A. M., Sablitzky, F., Littlewood, T. D., and Reth, M. 1996. Inducible sitedirected recombination in mouse embryonic stem cells. Nucleic Acids Res. 24: 543-548.

Zheng, B., Mills, A. A., and Bradley, A. 1999a. A system for rapid generation of coat color-tagged knockouts and defined chromosomal rearrangements in mice. Nucleic Acids Res. 27: 2354-2360.

Zheng, B., Sage, M., Cai, W. W., Thompson, D. M., Tavsanli, B. C., Cheah, Y. C., and Bradley, A. 1999b. Engineering a mouse balancer chromosome. Nat. Genet. 22: 375-378.

Zijlstra, M., Li, E., Sajjadi, F., Subramani, S., and Jaenisch, R. 1989. Germ-line transmission of a disrupted beta 2microglobulin gene produced by homologous recombination in embryonic stem cells. Nature 342: 435438.

Zweigerdt, R., Braun, T., and Arnold, H. H. 1997. Faithful expression of the Myf-5 gene during mouse myogenesis requires distant control regions: a transgene approach using yeast artificial chromosomes. Dev. Biol. 192: 172180. 


\section{Further Reading}

Caister Academic Press is a leading academic publisher of advanced texts in microbiology, molecular biology and medical research. Full details of all our publications at caister.com

- MALDI-TOF Mass Spectrometry in Microbiology Edited by: M Kostrzewa, S Schubert (2016) www.caister.com/malditof

- Aspergillus and Penicillium in the Post-genomic Era Edited by: RP Vries, IB Gelber, MR Andersen (2016) www.caister.com/aspergillus2

- The Bacteriocins: Current Knowledge and Future Prospects Edited by: RL Dorit, SM Roy, MA Riley (2016)

www.caister.com/bacteriocins

- Omics in Plant Disease Resistance Edited by: V Bhadauria (2016) www.caister.com/opd

- Acidophiles: Life in Extremely Acidic Environments Edited by: R Quatrini, DB Johnson (2016) www.caister.com/acidophiles

- Climate Change and Microbial Ecology: Current Research and Future Trend

Edited by: J Marxsen (2016)

www.caister.com/climate

- Biofilms in Bioremediation: Current Research and Emerging Technologies

Edited by: G Lear (2016)

www.caister.com/biorem

- Microalgae: Current Research and Applications Edited by: MN Tsaloglou (2016) www.caister.com/microalgae

- Gas Plasma Sterilization in Microbiology: Theory, Applications, Pitfalls and New Perspectives Edited by: H Shintani, A Sakudo (2016) www.caister.com/gasplasma

- Virus Evolution: Current Research and Future Directions Edited by: SC Weaver, M Denison, M Roossinck, et al. (2016) www.caister.com/virusevol

- Arboviruses: Molecular Biology, Evolution and Control Edited by: N Vasilakis, DJ Gubler (2016) www.caister.com/arbo

- Shigella: Molecular and Cellular Biology Edited by: WD Picking, WL Picking (2016) www.caister.com/shigella

-Aquatic Biofilms: Ecology, Water Quality and Wastewater Treatment

Edited by: AM Romaní, H Guasch, MD Balaguer (2016)

www.caister.com/aquaticbiofilms

- Alphaviruses: Current Biology

Edited by: S Mahalingam, L Herrero, B Herring (2016)

www.caister.com/alpha

- Thermophilic Microorganisms

Edited by: F Li (2015)

www.caister.com/thermophile
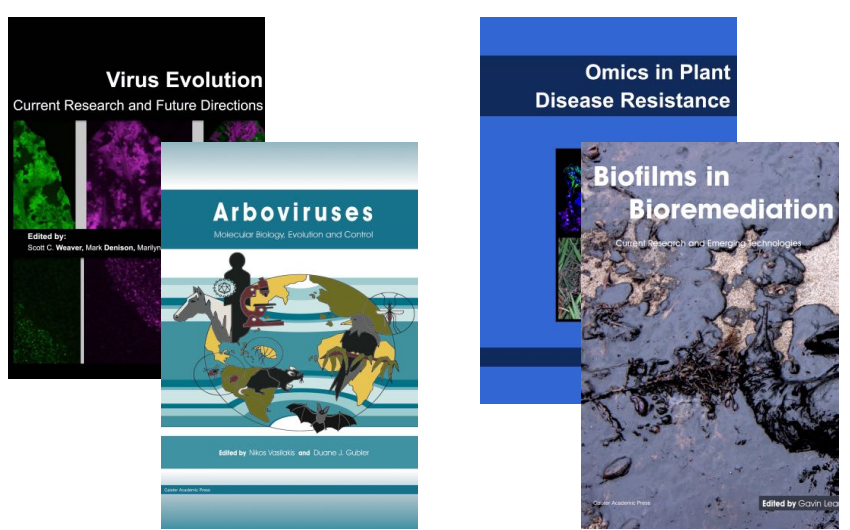
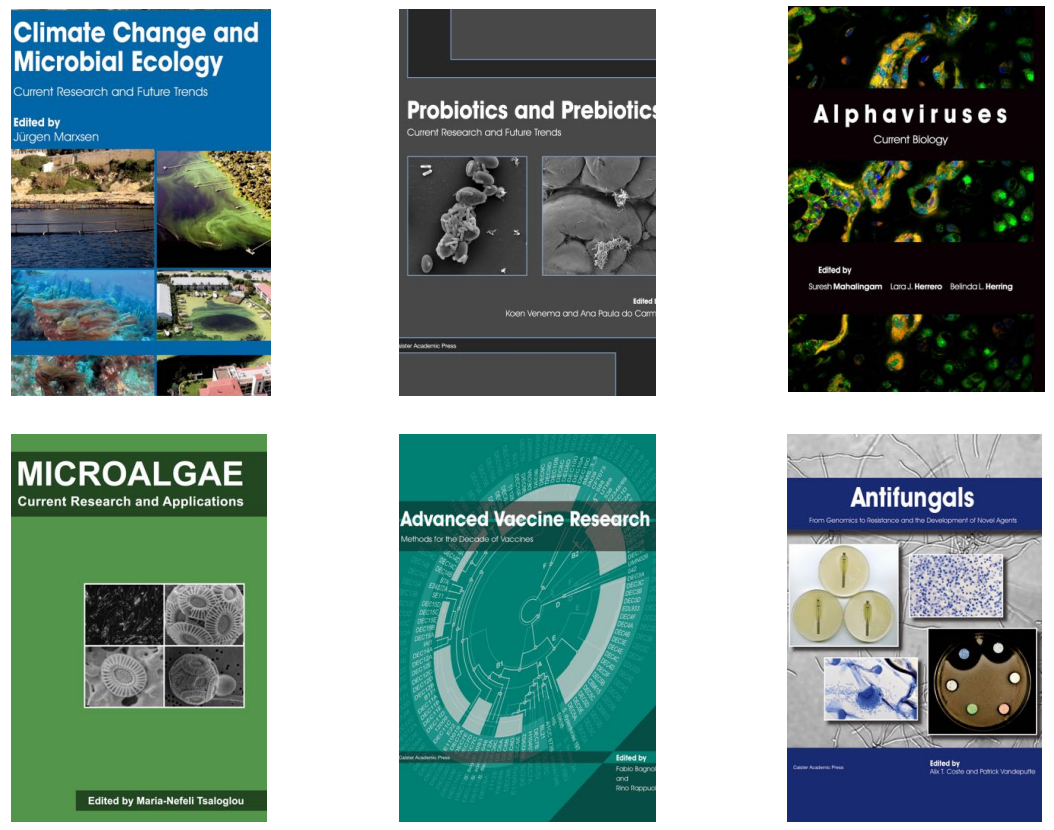

- Flow Cytometry in Microbiology: Technology and Applications Edited by: MG Wilkinson (2015) www.caister.com/flow

- Probiotics and Prebiotics: Current Research and Future Trends Edited by: K Venema, AP Carmo (2015) www.caister.com/probiotics

- Epigenetics: Current Research and Emerging Trends Edited by: BP Chadwick (2015) www.caister.com/epigenetics2015

- Corynebacterium glutamicum: From Systems Biology to Biotechnological Applications

Edited by: A Burkovski (2015)

www.caister.com/cory2

- Advanced Vaccine Research Methods for the Decade of Vaccines

Edited by: F Bagnoli, R Rappuoli (2015)

www.caister.com/vaccines

- Antifungals: From Genomics to Resistance and the Development of Novel Agents

Edited by: AT Coste, P Vandeputte (2015)

www.caister.com/antifungals

- Bacteria-Plant Interactions: Advanced Research and Future Trends Edited by: J Murillo, BA Vinatzer, RW Jackson, et al. (2015) www.caister.com/bacteria-plant

\section{- Aeromonas}

Edited by: J Graf (2015)

www.caister.com/aeromonas

- Antibiotics: Current Innovations and Future Trends

Edited by: S Sánchez, AL Demain (2015)

www.caister.com/antibiotics

- Leishmania: Current Biology and Contro Edited by: S Adak, R Datta (2015) www.caister.com/leish2

- Acanthamoeba: Biology and Pathogenesis (2nd edition) Author: NA Khan (2015)

www.caister.com/acanthamoeba2

- Microarrays: Current Technology, Innovations and Applications Edited by: Z He (2014)

www.caister.com/microarrays2

- Metagenomics of the Microbial Nitrogen Cycle: Theory, Methods and Applications

Edited by: D Marco (2014)

www.caister.com/n2 